Hydrol. Earth Syst. Sci. Discuss., 8, 3271-3304, 2011 www.hydrol-earth-syst-sci-discuss.net/8/3271/2011/ doi:10.5194/hessd-8-3271-2011

(C) Author(s) 2011. CC Attribution 3.0 License.
Hydrology and Earth System Sciences Discussions

\title{
Water table fluctuation and its effects on vegetation in a semiarid environment
}

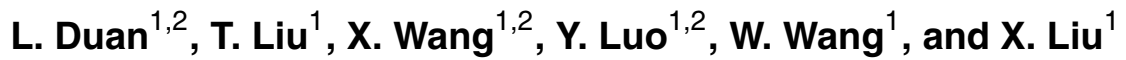

${ }^{1}$ College of Conservancy and Civil Engineering, Inner Mongolia Agricultural University, Hohhot 010018, China

${ }^{2}$ Hydrology and Watershed Engineering/Management Program, Department of Engineering and Physics, Tarleton State University, Stephenville 76402, USA

Received: 10 March 2011 - Accepted: 25 March 2011 - Published: 1 April 2011

Correspondence to: T. Liu (txliu1966@163.com)

Published by Copernicus Publications on behalf of the European Geosciences Union.

Water table fluctuation and its effects on vegetation

L. Duan et al.

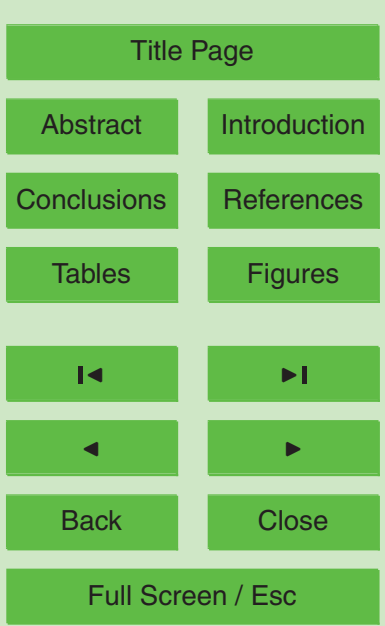

Printer-friendly Version

Interactive Discussion 


\section{Abstract}

A good understanding of water table fluctuation effects on vegetation is crucial for sustaining fragile hydrology and ecology of semiarid areas such as the Horqin Sandy Land (HSL) in northern China, but such understanding is not well documented in literature.

5 The objectives of this study were to examine spatio-temporal variations of water table and their effects on vegetation in a semiarid environment. A $9.71 \mathrm{~km}^{2}$ area within the HSL was chosen and well-instrumented to continuously measure hydrometeorologic parameters (e.g., water table). The area comprises of meadow lands and sandy dunes as well as transitional zones in between. In addition to those measured data, this study also used Landsat TM and MODIS imageries and meteorological data at a station near the study area. The spatio-temporal variations were examined using visual plots and contour maps, while the effects on vegetation were determined by overlaying a water table depth map with a vegetation index map derived from the MODIS imageries. The results indicated that water table was mainly dependent on local topography, localized 15 geological settings, and human activities (e.g., reclamation). At annual and monthly scales, water table was mainly a function of precipitation and potential evapotranspiration. A region within the study area where depth to water table was smaller tended to have better (i.e., more dense and productive) vegetation cover. Further, the results revealed that water table fluctuation was more sensitive for vegetations in the meadow lands than in the transitional zones, but it was least sensitive for vegetations in the sandy dunes.

\section{Introduction}

Groundwater is vital for sustaining fragial hydrology and ecology of semiarid areas (Cui and Shao, 2005), such as the Horqin Sandy Land located in northern China (Fig. 1).

25 The typical characteristics of these areas are that precipitation is much less than potential evapotranspiration (PET), resulting in very low topsoil moisture $(<10 \%$; Hao
HESSD

$8,3271-3304,2011$

Water table

fluctuation and its effects on vegetation

L. Duan et al.

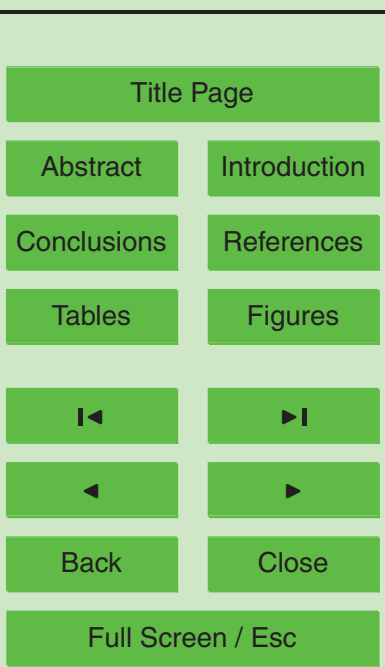

Printer-friendly Version

Interactive Discussion 
et al., 2010) and negligible surface water, and that vegetation primarily depends on groundwater for survival and development (Gries et al., 2003; Hipondoka et al., 2003; Lamontagne et al., 2005). Thus, for a given area, space-time fluctuations of groundwater control the vegetation species, structure, and diversity (Mahoney and Rood, 1992;

5 Robbins and Bell, 2000; Munoz-Reinoso, 2001; Riis and Hawes, 2002). Vegetation growth can be stressed when water table arises above a upper, or drops below a lower, threshold level. Using the data on water table and vegetation collected along 14 transects that were established on one side of the Tarim River in northwest China, Hao et al. (2010) found that depth to water table should be maintained at 2 to $4 \mathrm{~m}$ in the - vicinity of the water way and at 4 to $6 \mathrm{~m}$ for the rest of this arid area.

Based on a field study conducted in a San Pedro River riparian zone watershed located in the state of Arizona of the United States, Stromberg et al. (1996) found that wetland vegetation community was noticeably changed when depth to water table was elevated to 0 to $4 \mathrm{~m}$ and that obligate wetland herbs started to drastically decline when water table reached $0.25 \mathrm{~m}$ below ground surface. In the same riparian zone, Horton (2001) showed that depth to water table of between 2 and $4 \mathrm{~m}$ was suitable for vegetation growth as well as good for prevention of land desertification and soil salinization. This is consistent with Cui and Shao (2005) and Hao et al. (2010). In a California semiarid oak savanna, Miller et al. (2010) found that during dry season, groundwater uptake rates varied from 4 to $25 \mathrm{~mm}$ per month, which accounted for $80 \%$ of the total ET of a whole growing season, revealing the importance of groundwater in semiarid environment.

However, these studies focused on riparian zones and few studies addressed water table spatio-temporal variations as influenced by vegetation species (e.g., tall versus short grasses), topography, and environment factors (e.g., PET). Information is scarce in literature on how groundwater fluctuation affects vegetation development in long term and at large spatial scale. Understanding such effects is crucial for sustaining fragile environment of semiarid areas. The objectives of this study were to examine: (1) spatiotemporal variations of water table in a semiarid environment; and (2) how water table
HESSD

8, 3271-3304, 2011

\section{Water table \\ fluctuation and its effects on vegetation}

L. Duan et al.

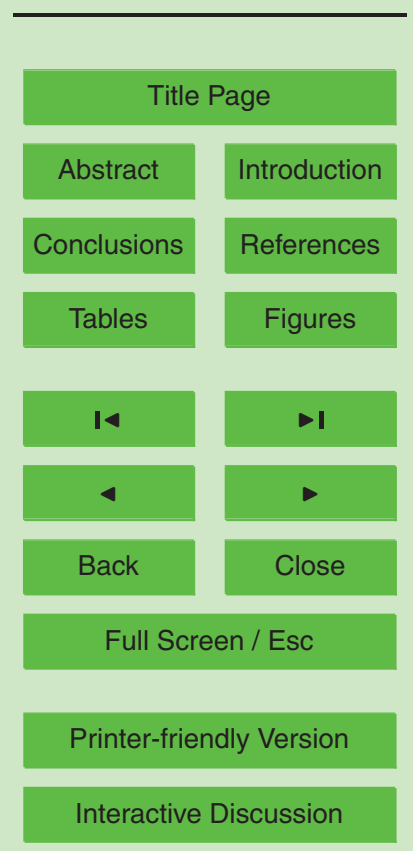


fluctuation affects vegetation development. The study was conducted in a selected area within the Horqin Sandy Land because this area is typical in terms of hydrology, topography, soil, and land cover.

\section{Materials and methods}

\section{$5 \quad 2.1$ Study area}

A $9.71 \mathrm{~km}^{2}$ area $\left(122^{\circ} 36.15^{\prime}\right.$ to $122^{\circ} 38.23^{\prime} \mathrm{E}, 43^{\circ} 19.25^{\prime}$ to $\left.43^{\circ} 21.10^{\prime} \mathrm{N}\right)$ within the $51700 \mathrm{~km}^{2}$ Horqin Sandy Land $\left(118^{\circ} 35^{\prime}\right.$ to $123^{\circ} 30^{\prime} \mathrm{E}, 42^{\circ} 41^{\prime}$ to $45^{\circ} 15^{\prime} \mathrm{N}$ ) (Fig. 1) was selected for this study because this area is a typical semiarid agro-pastoral transitional zone with diverse landscape features of sandy dune (54.5\%), meadow (26.6\%), agriculture (10.4\%), lake (5.2\%), and residential area (3.3\%). Based on Ma (2007), this area has a temperate and semiarid continental monsoonal climate, with an average annual precipitation of $389 \mathrm{~mm}$, of which $69.3 \%$ falls during the growing season (i.e., from June to August), and an average annual PET of about $1412 \mathrm{~mm}$. The average annual temperature is around $6.6^{\circ} \mathrm{C}$, with a minimum monthly mean temperature of $-13.3^{\circ} \mathrm{C}$ in January and a maximum temperature of $23.8^{\circ} \mathrm{C}$ in July. The average annual wind speed is $3.8 \mathrm{~m} \mathrm{~s}^{-1}$, with a minimum monthly mean wind speed of $3.0 \mathrm{~m} \mathrm{~s}^{-1}$ in August and a maximum of $5.0 \mathrm{~m} \mathrm{~s}^{-1}$ in April. The prevalent wind direction in winter and spring is northwest, whereas in summer and autumn it is southwest. The aquifer underneath the study area is composed of Quaternary loose sediments of a thickness ranging from 100 to $200 \mathrm{~m}$. The sediments are mainly fine sand (particle size from 0.074 to $0.42 \mathrm{~mm}$ ) in the upper layer of the aquifer, medium (particle size from 0.42 to $2.0 \mathrm{~mm}$ ) to fine sand in the mid layer, and coarse sand (particle size from 2.0 to $4.75 \mathrm{~mm}$ ) to gravel (particle size from 4.75 to $76 \mathrm{~mm}$ ) in the lower layer. Groundwater is mainly from precipitation and can either be lost to phreatic evaporation or discharged into the lake in the study
HESSD

$8,3271-3304,2011$

Water table

fluctuation and its effects on vegetation

L. Duan et al.

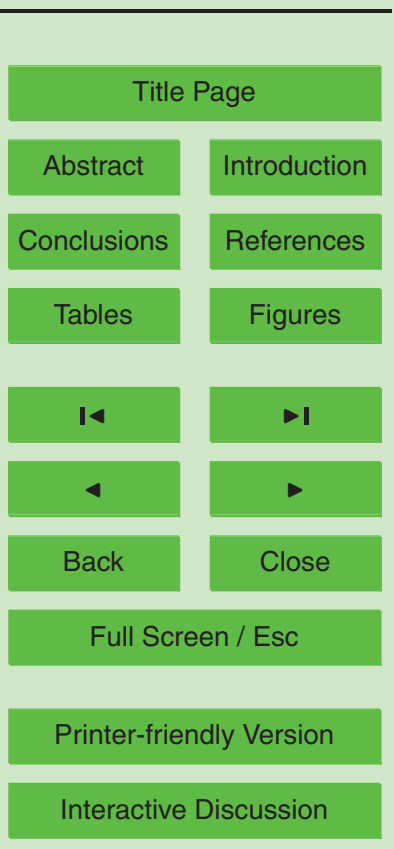


The combination of dry-windy climate and vulnerable sandy soils favors wind erosion, likely resulting in quick spread of desertification in this region (Wang, 2002) and largescale dust storms (Wang et al., 2006; Bagan et al., 2010). The study area, which has a topographic elevation varying from 186 to $232 \mathrm{~m}$ above mean sea level and is 5 mingled with rolling sandy dunes and desert as well as flat interdune (i.e., meadow) lowlands, agricultural land, and lakes, has an average dust storm outbreak frequency of 1.92 days per year. The sandy dunes are either bare or covered by sparse native plants, namely Artimisia halodendron, Caragana microphylla, Salix gordejevii, and/or Populus, whereas the lowlands are mainly covered with Leymus chinensis, Phragmites 10 australis, and/or Ixeris chinensis.

The Horqin Sandy Land, located between the Inner Mongolian Plateau and the Northeast China Plain (Fig. 1), is one of the four main sandy lands in northern China (Wu and $\mathrm{Ci}, 2001$ ) and an important part of the Inner Mongolia's grassland resources (Liu et al., 1996). However, the Horqin Sandy Land has undergone severe desertification in recent decades (He et al., 2008; Wang, et al., 2008) the desertified land has reached $57.8 \%$ of the Land's total area (Zhao et al., 2004), primarily because inappropriate reclamation for agriculture (e.g., chisel plough tillage in fall) and overgrazing (Zuo, et al., 2008) adversely altered the natural hydrologic conditions. As a result, most of the sandy grasslands have evolved into mobile, semi-mobile and/or semi-fixed dunes with severe, moderate or light desertification (Zhu and Chen, 1994; Guan et al., 2000). The increased frequency and intensity of dust storms (i.e., sandstorms) resulting from the desertification have resulted in serious environmental concerns not only for the adjacent rural areas but also for the major metropolis in China, including the country's capital city of Beijing, as well as in neighboring countries such as Japan and Korea (Takemi, et al., 2005). Similar concerns also exist in other regions in the world (Rooyen, 1998; Dey et al., 2004; Portnov and Safrielb, 2004). Thus, this study area can somewhat represent these systems, where groundwater is crucial for sustaining their fragile environments.

\section{HESSD}

$8,3271-3304,2011$

\section{Water table \\ fluctuation and its effects on vegetation}

L. Duan et al.

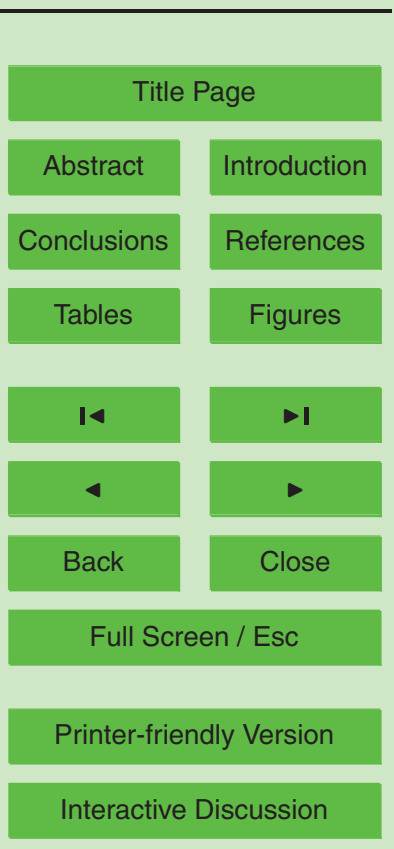




\subsection{Instrumentation and data collection}

The study area was instrumented in 2003 to continuously collect data on water table at 16 sites (Table 1) and hydrometeorology at site A3 and C3. Water table was measured using PC-2X transducer manufactured by the Yangguang Co. Ltd. 5 (http://jz322.shuoyi.com). For each observational well, a perforated iron pipe with an inner diameter of $5 \mathrm{~cm}$ was installed to prevent collapse of the well bore hole and to allow placement of the transducer. The wells have a depth of 5 to $15 \mathrm{~m}$ and a wellhead at 0.2 to $1.5 \mathrm{~m}$ above ground surface, depending on land cover and geographic location. The hydrometeorologic parameters, including rainfall, snowfall, sunshine duration, air unrecorded (i.e., manual) gauge or a sensor (Tables 2 and 3 ). These sites, maintained by the Agula Ecohydrological Experiment Station of the Inner Mongolia Agricultural University, were selected to monitor all combinations of the soils and land covers within the study area, and are named using combinations of the six letters from $A$ to $F$ with three numbers of 1, 2, and 3 and further grouped as KTS, GKTS, and GTS (Fig. 1 and Table 1) for description purposes. The sites are fenced by wire netting to prevent any unexpected interference from livestock and are accessible through narrow observation brick roads to minimize disturbance to the natural conditions.

Water table was measured every 5 days starting from 1 April 2003. Rainfall and snowfall were manually observed at KTS sites starting from 1 June 2006 by using Siphon rain gauge (Vasvári, 2005) and weighing method (Liu et al., 2002), respectively, on a daily basis. Sunshine duration was observed at KTS sites starting from 1 June 2007, on a daily basis, by using sunshine duration instrument (Michalsky, 1992). In June 2007, the KTS sites (i.e., site A3 and C3 in Table 1) were further equipped with automated sensors (Table 3 ) for rainfall, air temperature, relative humidity, wind speed, and barometric pressure. The acquisition time interval for these sensors was set to $30 \mathrm{~min}$. Data collected during periods when an instrument malfunctioned or was interfered by livestock were flagged as missing. The other data were checked in accordance with reasonable ranges of the parameters.
HESSD

$8,3271-3304,2011$

\section{Water table \\ fluctuation and its effects on vegetation}

L. Duan et al.

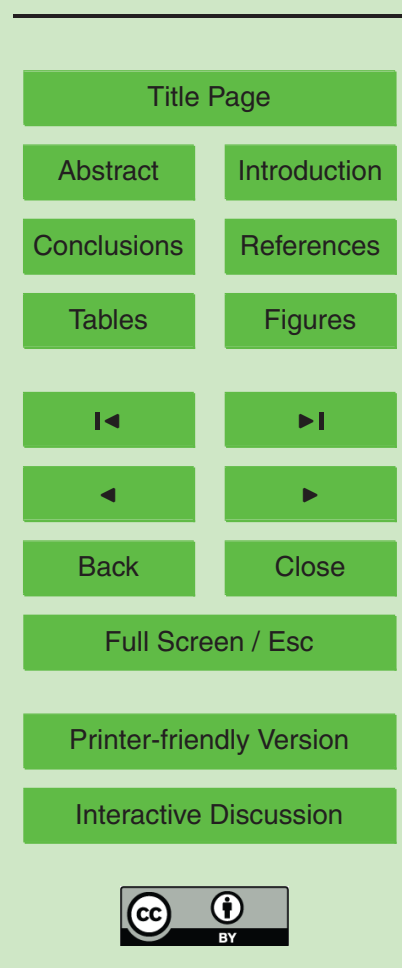




\subsection{Other data}

A contour map for the study area, which has an elevation interval of $2 \mathrm{~m}$ and is stored in a dwg format of AutoCAD ${ }^{\circledR} 2002$, was obtained from the Tongliao Survey and Design Institute of Water Conservancy and Hydropower (http://txl.dlztb.com/shejiyuan/201007/

5 13/442.html). This map was used to delineate the topographic variations and depths to water table in $\operatorname{ArcGIS}^{\circledR}$ 9.2. In addition, the available Landsat 4-5 Thematic Mapper (TM) images for the study area from April 2003 to December 2009 were downloaded from the United States Geological Survey (USGS) Earth Resource Observation and Science (EROS) website at http://glovis.usgs.gov/lmgViewer. These images were in10 terpreted to visually delineate boundaries of the three land covers (i.e., sandy dunes, transitional zones, and meadow lands) as well as long-term average seasonal sizes of the lake.

The Tongliao station $\left(122^{\circ} 16^{\prime} \mathrm{E}, 43^{\circ} 36^{\prime} \mathrm{N}\right)$, maintained by the Tongliao Aviation Agency and the Tongliao Survey and Design Institute of Water Conservancy and Hy15 dropower, is located at $43 \mathrm{~km}$ northwest of the study area (Fig. 1). The station has a ground elevation of $181 \mathrm{~m}$, which is about $10 \mathrm{~m}$ lower than the average elevation of the study area. This station was instrumented to collect hydrometeorologic data since 1951 . The measured daily values at this station for precipitation, air temperature, relative humidity, wind speed, barometric pressure, and sunshine duration were downloaded from the Chinese Meteorological Data Sharing Service System website http://cdc.cma.gov.cn, and used in this study to extend the measured time series of the study area.

Further, Moderate Resolution Imaging Spectroradiometer (MODIS) images of the study area for a period of April 2003 to December 2009 were downloaded from the National Aeronautics and Space Administration (NASA) Earth Observing System (EOS) website ftp://e4ft|01.cr.usgs.gov/MOLT/MOD13Q1.005. The images provide values of Normalized Difference Vegetation Index (NDVI) on a 16 day basis. In this study, NDVI was used to examine vegetation dynamics as influenced by water table fluctuation as
HESSD

$8,3271-3304,2011$

Water table

fluctuation and its effects on vegetation

L. Duan et al.

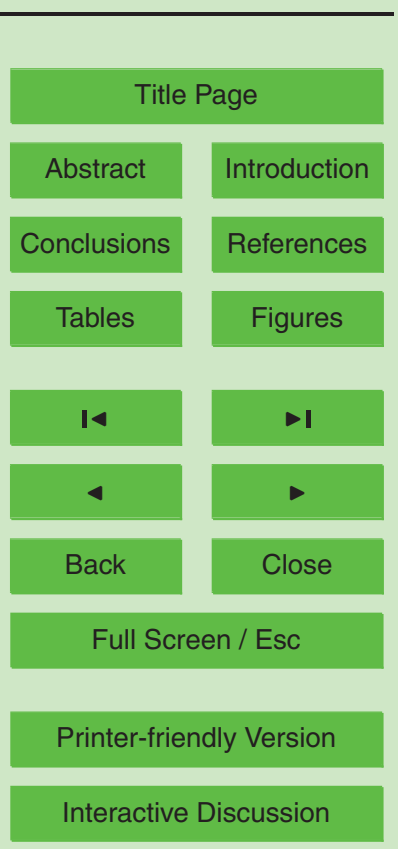


well as precipitation and evapotranspiration variations. NDVI compositely reflects leaf area index, biome, productivity, and percent vegetation cover (Huang et al., 2008). NDVI varies between -1 and 1 , with a greater value indicating better vegetation cover/growth. A negative NDVI value indicates no vegetation cover, while sparselyvegetated grounds have a NDVI value of 0 to 0.1 (Stow et al., 2003).

\subsection{Data preprocessing}

The number of years for which the parameters were measured varies from site to site (Table 2) and the measurement frequency at a given site is not consistent for all parameters. Thus, the raw data were first collapsed into a more manageable form. For 10 water table and for each observational well, daily values within a given month of a water year (December to November) were used to compute a median. This computed median was assumed as the mean monthly water table for that month of that year. Further, the monthly values for a given season (i.e., spring, summer, fall, or winter) of that same year were arithmetically averaged to compute the mean seasonal water table. The seasonal values of that same year in turn were arithmetically averaged to compute the mean annual water table. The mean annual values were arithmetically averaged across the six measurement years (i.e., 2004 to 2009) to compute the annual mean annual water table for that well. For a given season, its annual mean seasonal water table for that well was computed as the arithmetic average of the corresponding seasonal values across the six measurement years.

For a given land cover (i.e., sandy dunes, transitional zones, and meadow lands), the mean annual water table for a given water year was computed as the arithmetic average of the monthly water tables for the observational wells within the area of this land cover. The annual mean monthly water table for a given month was computed as 25 the arithmetic average of the monthly water tables for the observational wells within the area of this land cover and at this month across the six measurement years.

For a given day, the observed snowfall depth was multiplied by a prevalent conversion factor of 0.1 (Chang et al., 1982) to convert the snowfall into its equivalent water
HESSD

8, 3271-3304, 2011

\section{Water table \\ fluctuation and its effects on vegetation}

L. Duan et al.

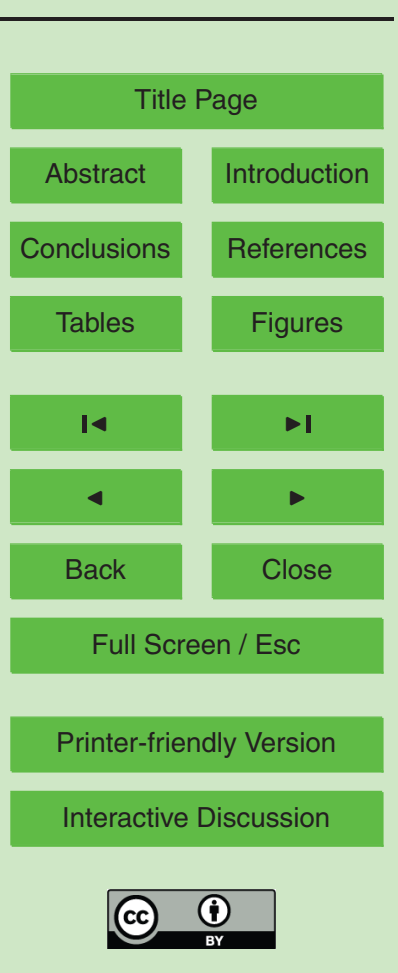


depth. The equivalent water depth was added to the observed rainfall on the same day to determine the daily precipitation. For air temperature, relative humidity, wind speed, or barometric pressure, its daily value for a given day was computed as the arithmetic average of the observed values in that day. For sunshine duration, its daily 5 value for a given day was determined as the summation of the observed values in that day. For each of these meteorological parameters, its areal value for a given day was computed as the arithmetic average of the daily values at site A3 and C3. In order to make these meteorological parameters have a time-series length coincident with that of water table, the computed areal daily values for a parameter were regressed in 10 Microsoft Excel ${ }^{\circledR}$ with respect to the corresponding measured daily values of that parameter at the Tongliao station (Fig. 2). As indicated by the large values of coefficient of determination $\left(R^{2}>0.7\right)$, the metrological parameters in the study area and those at the Tongliao station are well correlated. Subsequently, the regression equation for a meteorological parameter was used to estimate the areal daily values of that parameter 15 for a period from April 2003 to the starting measurement date (Table 2), during which daily values at the Tongliao station are available. As a result, a time-series dataset from 1 April 2003 to 31 December 2009 was created for these five meteorological parameters. Further, this dataset was used to compute site daily potential evaportranspiration (PET) using the FAO56 Penman-Monteith method (Monteith, 1965; Adeboye et al., 20 2009).

The computed daily precipitations for a given month were accumulated to determine the monthly precipitation of that month, and the monthly precipitations for a given season were accumulated to determine the seasonal precipitation. The seasonal values in turn were accumulated to compute the annual precipitation for each water year. This same procedure was used to determine monthly, seasonal, and annual PETs. In addition, the 16-day values of NDVI were extracted from the MODIS images for each of the six years (i.e., 2004 to 2009) and used to determine a maximum NDVI of that year. Previous studies (e.g., Cuomo et al., 2001; Hope et al., 2003; Stow et al., 2004) revealed that maximum NDVI can be a reliable indicator of vegetation cover and its

\section{HESSD}

8, 3271-3304, 2011

\section{Water table \\ fluctuation and its effects on vegetation}

L. Duan et al.

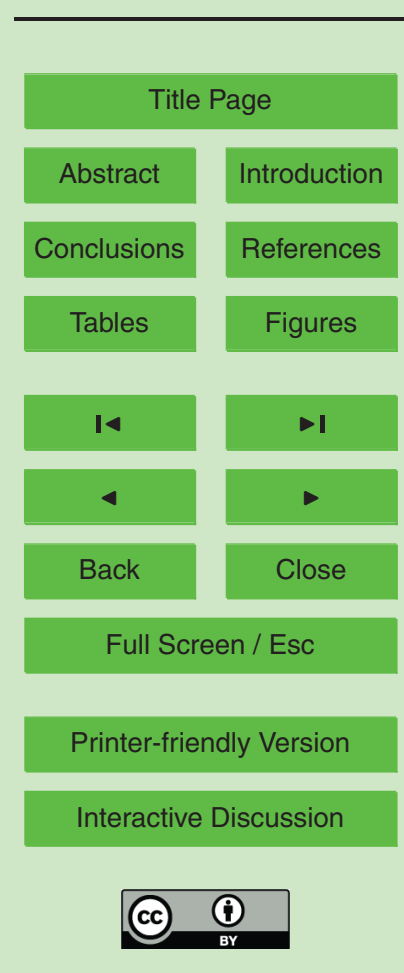


growth condition, and that a year with a larger value for maximum NDVI tends to have an overall better vegetation growth situation (i.e., a more dense vegetation cover) and vice versa. Further, the vector topographic map was rasterized using Raster Interpolation Tools of ArcGIS ${ }^{\circledR} 9.2$ to generate a 10-m digital elevation model (DEM).

\section{$5 \quad 2.5$ Analysis method}

The values for annual mean annual water table at the 16 observational wells were used in Surfer ${ }^{\circledR} 8.0$ to generate a contour map. This map was visually compared with the topographic map and the Landsat 4-5 TM image to examine the spatial patterns of water table as influenced by topography and land cover. Similarly, for each season, the values for annual mean seasonal water table at the 16 observational wells were used to generate a contour map of that season. The four seasonal contour maps were compared with each other as well as with the annual contour map to examine any discrepancies. In addition, visual plots were generated to examine the temporal trends of water table at annual and monthly time scales for each of the three land covers and site by site. Further, the temporal trends for a given time scale were examined to identify any causal relations with those of precipitation and PET at the same time scale.

The contour map of annual mean annual water table was rasterized using Raster Interpolation Tools of ArcGIS $^{\circledR} 9.2$ with a spatial resolution of $10 \mathrm{~m}$. This rasterized water table contour map was subtracted from the 10-m DEM to generate a grid map of annual mean annual depth to water table. This grid map in turn was converted in ArcGIS $^{\circledR} 9.2$ into a contour map of depth to water table. Subsequently, this contour map was overlain with the maximum NDVI grid to examine effects of water table fluctuation on vegetation growth and health. Moreover, the values of maximum NDVI were regressed with respect to factors of mean annual water table, precipitation and PET to
HESSD

$8,3271-3304,2011$

Water table

fluctuation and its effects on vegetation

L. Duan et al.

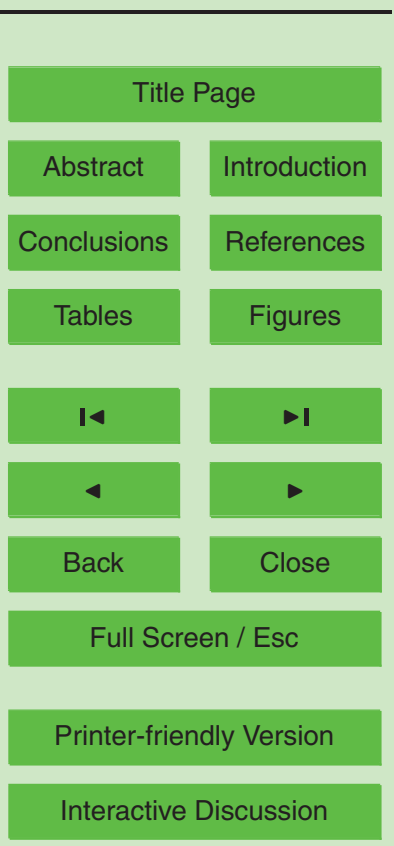




\section{Results and discussion}

\subsection{Water table spatial patterns}

Long-term (i.e., 2004 to 2009) annual mean annual water table exhibited an overall decrease pattern from the sandy areas in the south and north of the study area to 5 the transitional zones and then to the meadow lands in the middle (Fig. $3 a$ and b). Water table underneath the high-altitude $(191.8$ to $232.3 \mathrm{~m})$ peripheral sandy areas was almost $0.9 \mathrm{~m}$ higher than that underneath the medium-altitude $(188.2$ to $191.8 \mathrm{~m})$ transitional zones, which in turn was about $0.1 \mathrm{~m}$ higher than that underneath the lowaltitude $(187.1$ to $189.8 \mathrm{~m}$ ) meadow lands (Table 4$)$. This pattern follows that of the general topographic relief: the sandy areas have a higher altitude than the transitional zones, which in turn have a higher altitude than the meadow lands (Fig. 3b). The average overland gradient is around $3 \mathrm{~m}$ elevation drop per $100 \mathrm{~m}$ geographic distance (i.e., 3\%). Groundwater in the northwest of the study area either flows into the lake at a hydraulic gradient of 0.65 to $1.05 \%$ or to the sink surrounding site $\mathrm{C} 2(\mathrm{M})$ and $\mathrm{C} 2(\mathrm{G})$ at a greater gradient of $1.08 \%$. This sink was probably resulted from the localized geological settings (e.g., the higher ground spot between site D2 and C3 shown in Fig. 3b), which formed a geological slant against the southeasterly flowing groundwater (Sultan et al., 2004). Another probable explanation is that the natural water table surrounding the sink was lowered by agricultural activities (Fig. 1) to a level below which the groundwater flowing direction beyond site $\mathrm{C} 2(\mathrm{M})$ was reversed.

In addition, groundwater in the northeast of the study area flows into the lake at a much smaller hydraulic gradient of about $0.4 \%$, while groundwater in the south flows into the lake at a maximum gradient of up to $5.0 \%$. Further, water table in the north of the lake exhibited more spatial heterogeneities than that in the south (Fig. 3a). Again,

this can be attributed to the localized geological settings as well as groundwater consumptions by human, livestock, and crop. In contrast, the spatial variability of topography in the south is simpler (Fig. $3 b$ ) and had no phenomenal human activities.
HESSD

$8,3271-3304,2011$

Water table

fluctuation and its effects on vegetation

L. Duan et al.

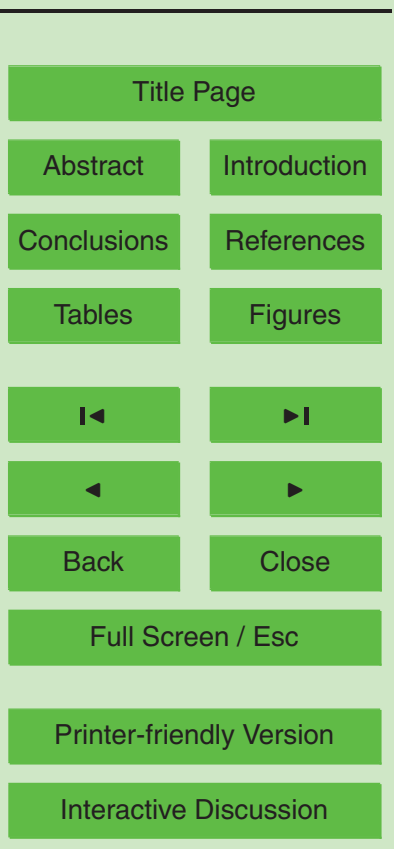


The aforementioned pattern also holds for long-term annual mean seasonal water table (Fig. 3c through 3f). Lake surface area was smaller in fall (September to November) than that of annual average, but it became larger in the other three seasons. Because the lake is solely fed by groundwater, the variation of lake surface area indicates that 5 water table fluctuated from season to season (Table 4). Fluctuation mainly occurred in the meadow and agricultural lands, where the depth to water table was usually less than $2.0 \mathrm{~m}$ and thus could be directly influenced by seasonally varied precipitation and evapotranspiration as discussed in the following context. For a given location in the lands, water table was up to $0.1 \mathrm{~m}$ lower in summer and fall than in spring and win10 ter. The explanation is that vegetation (e.g., Leymus chinensis) and crop uptook more groundwater during growing season as well as that phreatic evaporation tended to increase with decrease of depth to water table in summer and fall. In contrast, water table in the south of the lake exhibited negligible variations from season to season because of larger depths to water table $(>4.0 \mathrm{~m})$. For the sandy dunes, water table tended to drop marginally from spring to winter as a result of water table fluctuation in the transitional zones and meadow lands. Water table in the transitional zones declined from spring to fall, but it had no detectable changes from fall to winter.

\subsection{Water table temporal trends}

For a given water year (December to November), mean annual water table was de20 was gradually increasing before 2006 as a result of moderately high precipitation and low PET, but it started to decline after that year because the abnormally large PET (>2200 mm) in 2007 depleted soil water and thus resulted in a more-than-normal soil storage in the subsequent years. The increased soil storage tended to diminish replenishment of infiltrated water to the aquifer. However, the large precipitation $(\approx 450 \mathrm{~mm})$ in 2008 slightly increased $(0.08 \mathrm{~m})$ water table underneath the meadow lands and
HESSD

$8,3271-3304,2011$

\section{Water table \\ fluctuation and its effects on vegetation}

L. Duan et al.

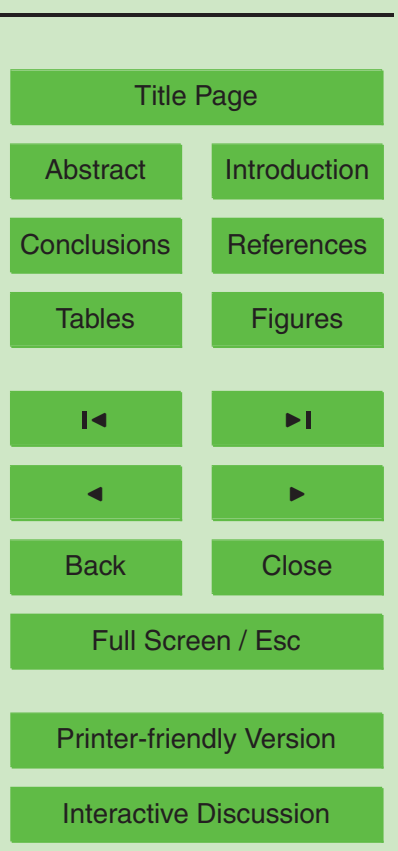


decelerated decline speed of water table underneath the transitional zones as well as the sandy areas. In addition, because of a smallest depth to water table $(<2.0 \mathrm{~m})$, water table underneath the meadow lands exhibited most sensitive responses to precipitation and PET. The less fluctuation of water table underneath the other two types 5 of land covers was partially due to the greater depths to water table $(>2.5 \mathrm{~m})$. Also, because of a larger permeability $\left(>415 \mathrm{~mm} \mathrm{~h}^{-1}\right)$ of the sand soils in the sandy areas and transitional zones, a dry topsoil layer could be imminently formed after a precipitation event (Yamanaka et al., 1998; Mutziger et al., 2005; Romano and Giudici, 2009). This dry layer tended to restrict further soil evaporation, allowing more percolation into the 10 aquifer underneath.

Compared with mean annual water table, annual mean monthly water table exhibited much smaller temporal variations for all three land covers (Fig. 5). The replenishment effect of increased precipitation in summer (June to August) was offset by elevated PET, while precipitation in other three seasons was too small to cause a noticeable increase of water table. In winter (December to February) and spring (March to May), water table exhibited a gradual increase trend because of low PET. In fall (September to November), because precipitation was used to replenish soil water depleted in summer, water table exhibited a marginal decrease trend. In contrast, monthly mean water table varied greatly within a water year in response to precipitation and PET for all three land covers

(Fig. 6). Throughout three winter months, water table exhibited a marginally decrease trend because precipitation was in the form of snowfall and thus could not replenish the aquifer and also because PET was near zero. Throughout three spring months, snowmelt and additional rainfall tended to increase water table but this replenishment effect was partially offset by elevated PET. For summer months, water table exhibited an overall decrease trend because of maximum PET. The sharp increases of the water tables in July of 2005 and 2008 were caused by the large rainfall events occurred in June $2005(139 \mathrm{~mm})$ and July $2008(238 \mathrm{~mm})$, respectively. Similarly, for fall months, water table exhibited an overall decrease trend though PET started to decline. This can mainly be attributed to reduced rainfall. Because depths to water table of the three
HESSD

$8,3271-3304,2011$

\section{Water table \\ fluctuation and its effects on vegetation}

L. Duan et al.

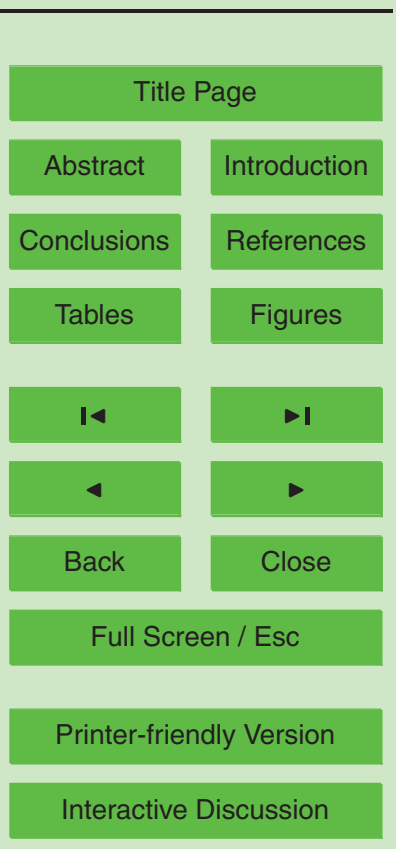

Interactive Discussion 
land covers are distinctly different, water table underneath the meadow lands exhibited quicker responses (i.e., fluctuations) than that underneath the transitional zones, which in turn exhibited more sensitive responses than that underneath the sandy areas.

\subsection{Effects of Water table variation on vegetation}

5 Within the study area, a region with a smaller depth to water table tended to have a better (i.e., more dense and productive) vegetation cover, as indicated by a larger value for maximum NDVI (Fig. 7). Vegetation cover was best in the meadow lands where depth to water table was less than $2 \mathrm{~m}$, while it was worst in the sandy areas where depth to water table was greater than $4 \mathrm{~m}$. Vegetation cover in the transitional 10 zones, where depth to water table varied from 0.6 to $3 \mathrm{~m}$, exhibited noticeable spatial variations. These findings are not in agreement with those of Horton (2001) and Hao et al. (2010) because riparian zones and areas away from water way have distinctly different groundwater cycling mechanisms (Brutsaert and Sugita, 2008).

Across the meadow lands, the southeastern region had a depth to water table of 15 only up to $1.4 \mathrm{~m}$ and thus was covered by well-developed vegetations, as indicated by a value for maximum NDVI of 0.7 or larger. However, toward the northwest and/or east vegetation development exhibited a deterioration trend, as indicated by the decreasing NDVI. One explanation is that the increasing depth to water table tended to limit the amount of groundwater available for vegetation transpiration (Cui and Shao, 2005; Hao et al., 2010). Another explanation is that the intensive human activities (e.g., farming) destroyed natural vegetations, resulting in a poorer vegetation cover. The impacts of the human activities can be further verified by that the eastern region, where the depth to water table was also less than $1.4 \mathrm{~m}$, had a just fairly-developed vegetation cover (maximum NDVI $=0.5$ to 0.6 ). The meadow lands in the south alongside of the lake (Fig. 7) had a depth to water table of less than $0.8 \mathrm{~m}$ but had a moderately poor or fair vegetation cover (maximum NDVI $=0.4$ to 0.6 ). This can be attributed to that this
HESSD

$8,3271-3304,2011$

Water table

fluctuation and its effects on vegetation

L. Duan et al.

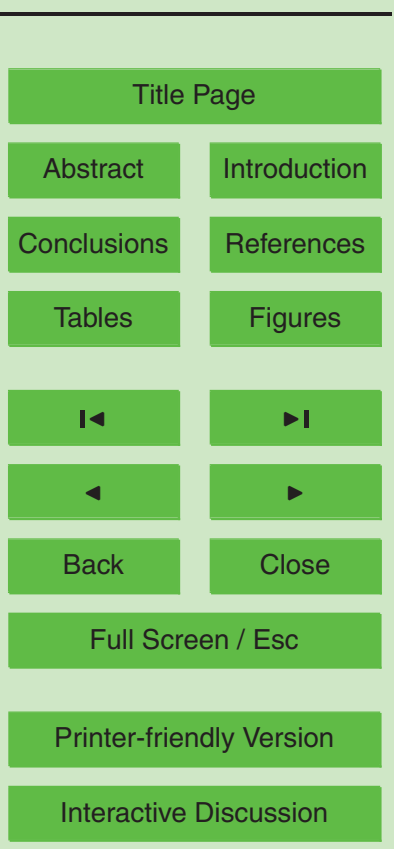

Interactive Discussion 
region, with dominant hydrophyte vegetation of Phragmites australis (Table 2), was subjected to frequent inundation and soil erosion and salinization as a result of lake water surface fluctuation.

Across the sandy dunes, vegetation cover exhibited fewer spatial patterns, as indi5 cated by smaller variations ( 0.2 to 0.4$)$ of maximum NDVI (Fig. 7$)$. This can partially be attributed to that depth to water table in this region was too deep (>4 m) for groundwater fluctuation to exert direct influences on vegetation development (Cui and Shao, 2005). Similarly, because the upper transitional zone had a depth to water table of greater than $2 \mathrm{~m}$, vegetation cover across this zone exhibited slight variations only. In contrast, 10 vegetation cover across the lower transitional zone, where depth to water table was less than $2 \mathrm{~m}$, exhibited a spatial pattern of noticeable improvement from the east to the west. The value for maximum NDVI is 0.4 to 0.5 in the east, while it increases to 0.6 in the west.

For a given region within the study area, vegetation cover, as measured by maxi15 mum NDVI, varied from year to year (Fig. 8). A multiple regression analysis revealed that the temporal variation was statistically dependent on $\left(R^{2}>0.99\right)$ water table, precipitation, and PET. Water table explained 42,38 , and $7 \%$ of the variations presented by the maximum NDVI for meadow lands, transitional zones, and sandy dunes, respectively, while PET explained 25, 7, and 30\%, respectively. Precipitation explained 3,17 , and $8 \%$ of the variations for meadow lands, transitional zones, and sandy dunes, respectively. These imply that water table fluctuation was more sensitive for vegetations in the meadow lands than in the transitional zones, and was least sensitive for vegetations in the sandy dunes because of the deep water table underneath the sandy dunes. In addition, climate, as comprehensively reflected by PET, had more direct intransitional zones. This is probably because the relation between PET and actual transpiration became weak at depth to water table of 0.8 to $2.0 \mathrm{~m}$ (Hao et al., 2010) in the transitional zones. The least influence of precipitation for the meadow lands can be attributed to that regardless, the already high water table in this region made groundwater
HESSD

8, 3271-3304, 2011

\section{Water table \\ fluctuation and its effects on vegetation}

L. Duan et al.

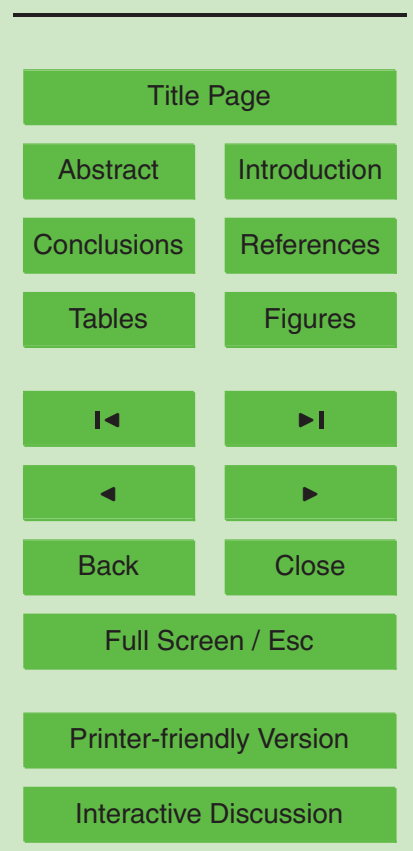


always available for vegetation transpiration. In contrast, precipitation could increase soil moisture in the thick dry soil profiles of the transitional zones and sandy dunes, and thus enhance the relation between PET and actual transpiration. As a result, precipitation had more direct influences on vegetation in these two regions.

\section{Conclusions}

This study examined spatio-temporal variations of water table underneath a $9.71 \mathrm{~km}^{2}$ area within the semiarid Horqin Sandy Land located in northern China using the data collected from 2003 to 2009, Landsat 4-5 TM and MODIS images, and meteorological data at the Tongliao station. The examination was implemented by generating and - cross-comparing various visualization plots and contour maps and by a multiple regression analysis. The results indicated that for the study area, the spatial patterns of water table were mainly controlled by local topography, localized geological settings, and human activities, while the temporal trends were mainly dependant on precipitation and PET. As a result of long-term reclamation for agriculture (e.g., site C2(M)), 15 water table was lowered by $0.3 \mathrm{~m}$ relative to that underneath the adjacent area (e.g., site $\mathrm{C} 2(\mathrm{G})$ ) where human disturbance is minimal. Within the study area, a region with a smaller depth to water table tended to have better (i.e., more dense and productive) vegetation cover, as indicated by a larger value $(>0.7)$ for maximum NDVI. Further, the results showed that vegetation development was statistically dependent on $\left(R^{2}>0.99\right)$ 20 water table, precipitation, and PET. Water table explained 42,38 , and $7 \%$ of the variations presented by the maximum NDVI for the meadow lands, transitional zones, and sandy dunes, respectively. This implies that water table fluctuation was more sensitive for vegetations in the meadow lands than in the transitional zones, but fluctuation was least sensitive for vegetation in the sandy dunes. A reasonable generalization of these results is that groundwater is a controlling hydrologic factor for fragile ecosystems in arid and semiarid environment.

HESSD

$8,3271-3304,2011$

\section{Water table \\ fluctuation and its effects on vegetation}

L. Duan et al.

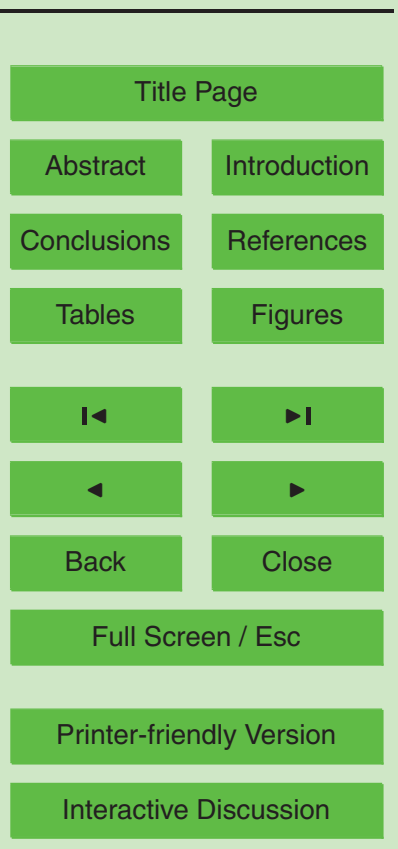


Acknowledgements. This research was financially supported by the Inner Mongolia Agricultural University Innovation Team Building Program Cold-Arid Region Water Resources Utilization Grant \# NDTD2010-6, National Natural Science Foundation of China under contract \#51069005, Chinese Ministry of Science and Technology under contract \#2010DFA71460, and

5 Inner Mongolia Scientific and Technology Bureau under contract \#20090516. The authors appreciate the following people for field instrumentation and data collection: Dakang Liu, Changxiang Yu, Hailing Wang, Xiaoyan Liu, Shiqiang Li, Yangyang Hu, Li Wang, Lei Ding, Fengliang Wei, and Yao Wu. Our thanks are extended to James Pierce, Dean of College of Science and Technology, and Daniel Marble, Head of Engineering and Physics Department, at Tarleton 10 State University, for sponsoring the primary author (Duan) and one co-author (Luo) to conduct this research as international visiting scholars.

\section{References}

Adeboye, O. B., Osunbitan, J. A., Adekalu, K. O., and Okunade, D. A.: Evaluation of FAO-56 Penman-Monteith and temperature based models in estimating reference evapotranspiration using complete and limited data, application to Nigeria, Agr. Eng. Int.: CIGR Journal, 6, 1-25, 2009.

Bagan, H., Takeuchi, W., Kinoshita, T., Bao, Y., and Yamagata, Y.: Land cover classification and change analysis in the Horqin Sandy Land from 1975 to 2007, IEEE J. Sel. Top. Appl., 3(2), 168-177, doi:10.1109/JSTARS.2010.2046627, 2010.

Brutsaert, W. and Sugita, M.: Is Mongolia's groundwater increasing or decreasing? The case of the Kherlen River basin, J. Hydrol. Sci., 53(6), 1221-1229, 2008.

Chang, A. T. C., Foster, J. L., Hall, D. K., Rango, A., and Hartline, B. K.: Snow water equivalent estimation by microwave radiometry, Cold Reg. Sci. Technol., 5, 259-267, 1982.

Cui, Y. and Shao, J.: The role of groundwater in arid/semiarid ecosystems, Northwest China, Ground Water, 43(4), 471-477, 2005.

Cuomo, V., Lanfredi, M., Lasaponara, R., Macchiato, M. F., and Simoniello, T.: Detection of inter-annual variation of vegetation in middle and southern Italy during 1985-1999 with $1 \mathrm{~km}$ NOAA AVHRR, J. Geophys. Res., 106(D16), 17863-17876, doi:10.1029/2001JD900166, 2001.

Dey, S., Tripathi, S. N., Singh, R. P., and Holben, B. N.: Influence of dust storms on the aerosol
HESSD

8, 3271-3304, 2011

\section{Water table \\ fluctuation and its effects on vegetation}

L. Duan et al.

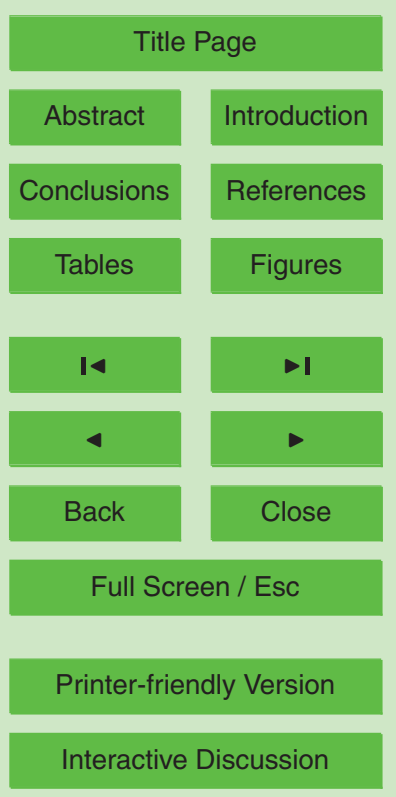


optical properties over the Indo-Gangetic basin, J. Geophys. Res.-Atmos., 109, D20211, doi:10.1029/2004JD004924, 2004.

Gries, D., Zeng, F., Foetzki, A., Arndt, S. K., Bruelheide, H., Thomas, F. M., Zhang, X., and Runge, M.: Growth and water relations of Tamarix ramosissima and Populus euphratica on Taklamakan desert dunes in relation to depth to a permanent water table, Plant. Cell. Environ., 26, 725-736, 2003.

Guan, W., Zeng, W., and Jiang, F.: Ecological studies on the relationship between the process of desertification and vegetation dynamics in the west of Northeast China: community diversity and desertification process, Acta Ecological Sinica, 20, 93-98, 2000 (in Chinese).

Hao, X., Li, W., Huang, X., Zhu, C., and Ma, J.: Assessment of the groundwater threshold of desert riparian forest vegetation along the middle and lower reaches of the Tarim River, China, Hydrol. Process., 24, 178-186, doi:10.1002/hyp.7432, 2010.

He, S., Qiu, L., Jiang, D., Lamusa, A., Liu, Z., and Luo, Y.: Sand-fixing effects of Caragana microphylla shrub in Horqin Sandy, Frontiers of Forestry in China, 3(1), 31-35, 2008 (in 15 Chinese).

Hipondoka, M. H. T., Araniba, J. N., Chirara, C., Lihavha, M., and Macko, S. A.: Vertical distribution of grass and tree roots in arid eco-systems of Southern Africa: niche differentiation of competition, J. Arid Environ., 54(2), 319-325, doi:10.1006/jare.2002.1093, 2003.

Hope, A. S., Boynton, W. L., Stow, D. A., and Douglas, D. C.: Inter-annual growth dynamics of vegetation in the Kuparuk River watershed based on the normalized difference vegetation index, Int. J. Remote Sens., 24(17), 3413-3425, doi:10.1080/0143116021000021170, 2003.

Horton, J. L.: Physiological response to groundwater depth varies among species and with river flow regulation, Ecol. Appl., 11(4), 1046-1059, 2001.

Huang, F., Wang, P., and Liu, X.: Monitoring vegetation dynamic in Horqin Sandy Land from SPOT Vegetation Time series Imagery, The International Archives of the Photogrammetry, Remote Sensing and Spatial Information Sciences, XXXVII, 915-920, 2008.

Lamontagne, S., Cook, P. G., O'Grady, A., and Eamus, D.: Groundwater use by vegetation in a tropical savanna riparian zone (Daly River, Australia), J. Hydrol., 310, 280-293, doi:10.1016/j.jhydrol.2005.01.009, 2005.

30 Liu, C., Zhang, X., and Zhang, Y.: Determination of daily evaporation and evapotranspiration of winter wheat and maize by large-scale weighing lysimeter and micro-lysimeter, Agr. Forest Meteorol., 111, 109-120, doi:10.1016/S0168-1923(02)00015-1, 2002.

Liu, X., Zhao, H., and Zhao, A.: Windblown-sand environment and vegetation in the Horqin
HESSD

8, 3271-3304, 2011

\section{Water table \\ fluctuation and its \\ effects on vegetation}

L. Duan et al.

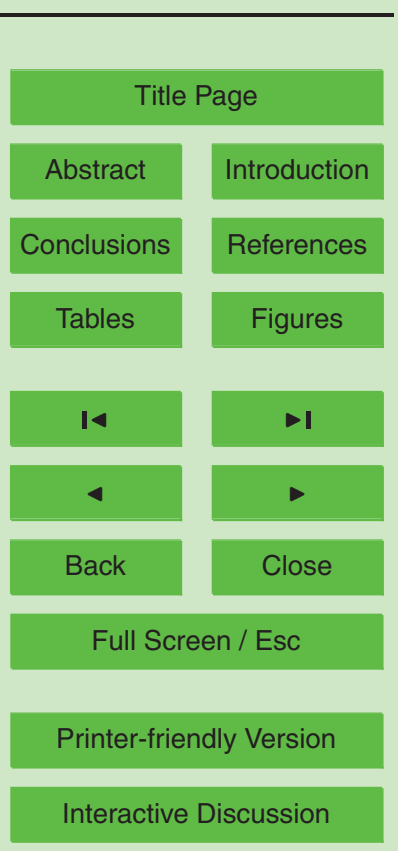


Sandy Land, China, Science Press, Beijing, 1996.

Ma, L.: Study on surface environment changes and the response relationships between the former changes and hydrological-weather factors in Horqin Sandy Land, Ph. D. thesis, Inner Mongolia Agricultural University, 158 pp., 2007.

5 Mahoney, J. M. and Rood, S. B.: Response of a hybrid poplar to water table decline in different substrates, Forest Ecol. Manag., 54(1-4), 141-156, doi:10.1016/0378-1127(92)90009-X, 1992.

Michalsky, J. J.: Comparison of a national weather service foster sunshine recorder and the World Meteorological Organization standard for sunshine duration, Sol. Energy, 48(2), 133$10 \quad 141,1992$.

Miller, G. R., Chen, X., Rubin, Y., Ma, S., and Baldocchi, D. D.: Groundwater uptake by woody vegetation in a semiarid oak savanna, Water Resour. Res., 46, W10503.1-W10503.14, doi:10.1029/2009WR008902, 2010.

Monteith, J. L.: Evaporation and environment. In State and Movement of Water in Living Organ15 isms: Proc. 19th Symp. Society of Experimental Biology, 205-234, Cambridge, UK, Cambridge University Press, 1965.

Munoz-Reinoso, J. C.: Vegetation changes and groundwater abstraction in SW Doñana, Spain, J. Hydrol., 242(3-4), 197-209, doi:10.1016/S0022-1694(00)00397-8, 2001.

Mutziger, A. J., Burt, C. M., Howes, D. J., and Allen, R. G.: Comparison of measured and FAO-56 modeled evaporation from bare Soil, J. Irrig. Drain. E-ASCE, 131(1), 59-72, 2005.

Portnov, B. A. and Safrielb, U. N.: Combating desertification in the Negev: dryland agriculture vs. dryland urbanization, J. Arid Environ., 56(4), 659-680, doi:10.1016/S01401963(03)00087-9, 2004.

Riis, T. and Hawes, I.: Relationships between water level fluctuations and vegetation diversity in shallow water of New Zealand lakes, Aquat. Bot. 74(2), 133-148, doi:10.1016/S03043770(02)00074-8, 2002.

Robbins, B. D. and Bell, S. S.: Dynamics of a subtidal seagrass landscape: seasonal and annual change in relation to water depth, Ecology, 81(5), 1193-1205, 2000.

Romano, E. and Giudici, M.: On the use of meteorological data to assess the evaporation from a bare soil, J. Hydrol., 372, 30-40, doi:10.1016/j.jhydrol.2009.04.003, 2009.

Rooyen, A. F. V.: Combating desertification in the southern Kalahari: connecting science with community action in South Africa, J. Arid Environ., 39(2), 285-297, doi:10.1006/jare.1998.0407, 1998.
HESSD

8, 3271-3304, 2011

\section{Water table \\ fluctuation and its effects on vegetation}

L. Duan et al.

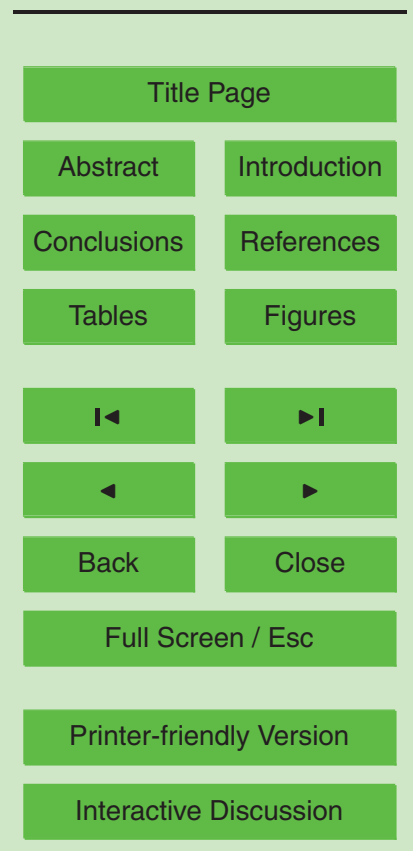


Stow, D., Daeschner, S., Hope, A., Douglas, D., Petersen, A., Myneni, R., Zhou, L., and Oechel, W.: Variability of the seasonally integrated Normalized Difference Vegetation Index across the north slope of Alaska in the 1990s, Int. J. Remote Sen., 24(5), 1111-1117, doi:10.1080/0143116021000020144, 2003.

5 Stow, D., Hope, A., McGuire, D., Verbyla, D., and Gamon, D.: Remote sensing of vegetation and land-cover change in Arctic Tundra Ecosystems, Remote Sens. Environ., 89, 281-308, doi:10.1016/j.rse.2003.10.018, 2004.

Stromberg, J. C. and Tiller, R.: Effect of groundwater decline on riparian vegetation of semiarid region: The San Pedro, Arizona, Ecol. Appl., 61(1), 113-131, 1996.

10 Takemi, T.: Explicit simulations of convective-scale transport of mineral dust in severe convective weather, J. Meteorol. Soc. Jpn, (Ser. II), 83(A), 187-203, 2005.

Vasvári, V.: Calibration of tipping bucket rain gauges in the Graz urban research area, Atmos. Res., 77, 18-28, doi:10.1016/j.atmosres.2004.12.012, 2005.

Wang, G.: Simulation analysis for water transforming based on field test for GSPAC system 15 in dune - meadow - dune area in Horqin Sand, Ph. D. thesis, Inner Mongolia Agricultural University, 117 pp., 2008.

Wang, T.: Sandy desertification in the North of China, Sci. China Ser. D, 45, 23-34, doi:10.1007/BF02878385, 2002.

Wang, X., Oenema, O., Hoogmoed, W. B., Perdok, U. D., and Cai, D.: Dust storm erosion and its impact on soil carbon and nitrogen losses in Northern China, CATENA, 66(3), 221-227, doi:10.1016/j.catena.2006.02.006, 2006.

$\mathrm{Wu}, \mathrm{B}$. and Ci, L.: Landscape change and desertification development in the Mu Us Sandland, J. Arid Environ., 47, 429-444, doi:10.1006/jare.2001.0847, 2001.

Yamanakaa, T., Takeda, A., and Shimada, J.: Evaporation beneath the soil surface: some observational evidence and numerical experiments, Hydrol. Process., 12, 2193-2203, 1998.

Zhao, H., Zhao, X., Zhang, T., and Wu, W. (Eds.): Desertification processes and its restoration mechanisms in the Horqin Sand Land, China Ocean Press, Beijing, 2004.

Zhu, Z. and Chen, G.: Sandy desertification in China, Science Press, Beijing, 1994.

Zuo, X., Zhao, X., Zhang, T., Guo, Y., Wang, S., and Drake, S.: Spatial pattern and heterogeneity of soil properties in sand dune under grazing and restoration in Horqin Sandy Land, Northern China, Soil Till. Res., 99, 202-212, doi:10.1016/j.still.2008.02.008, 2008.

\section{HESSD}

$8,3271-3304,2011$

\section{Water table \\ fluctuation and its effects on vegetation}

L. Duan et al.

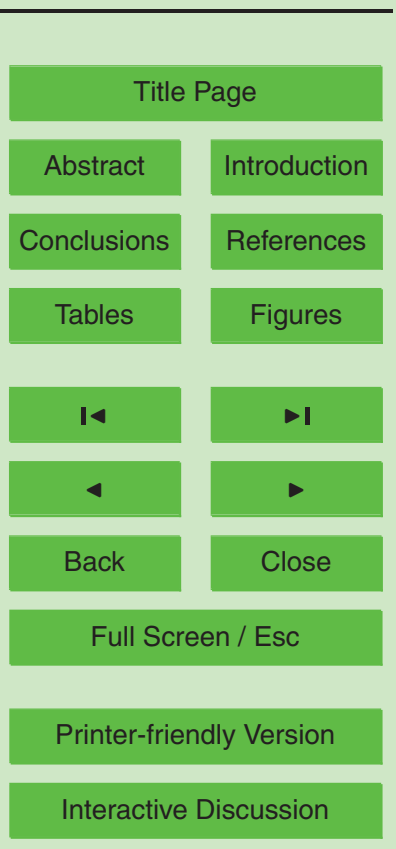




\section{HESSD}

8, 3271-3304, 2011

Table 1. Characteristics of the water table and hydrometeorologic sites.

\begin{tabular}{|c|c|c|c|c|c|c|}
\hline Site & Group & $\begin{array}{l}\text { Land } \\
\text { cover }\end{array}$ & $\begin{array}{l}\text { Soil } \\
\text { texture }\end{array}$ & $\begin{array}{l}\text { Elevation } \\
\text { (m) }\end{array}$ & $\begin{array}{l}\text { Dominant } \\
\text { vegetation }\end{array}$ & $\begin{array}{l}\text { Vegetaition } \\
\text { density (\%) }\end{array}$ \\
\hline A3 & KTS & Mobile dune & Sand & 199.35 & Artimisia halodendron & $<20$ \\
\hline C3 & & Meadow & Sandy loam & 188.50 & Leymus chinensis & $>50$ \\
\hline A1 & GKTS & Fixed dune & Sand & 194.20 & Populus & $>40$ \\
\hline B2 & & Fixed dune & Sand & 190.87 & Artimisia halodendron & $>40$ \\
\hline $\mathrm{C} 2(\mathrm{G})$ & & Meadow & Loamy sand & 188.60 & Leymus chinensis & 20 to 50 \\
\hline C2(M) & & Meadow & Loamy sand & 188.51 & Zea Mays L. & $>50$ \\
\hline D1 & & Meadow & Sandy loam & 188.52 & Leymus chinensis & 5 to 20 \\
\hline $\mathrm{E} 1$ & & Fixed dune & Sand & 190.89 & Artimisia halodendron & $>40$ \\
\hline $\mathrm{E} 2(\mathrm{U})$ & & Meadow & Sandy loam & 189.59 & $\begin{array}{l}\text { Leymus Chinensis, } \\
\text { Phragmites australis, } \\
\text { Ixeris chinensis }\end{array}$ & 20 to 50 \\
\hline E3(U) & & Meadow & Sandy loam & 188.42 & $\begin{array}{l}\text { Leymus Chinensis, } \\
\text { Phragmites australis, } \\
\text { Ixeris chinensis }\end{array}$ & $>50$ \\
\hline F1 & & Fixed dune & Sand & 196.73 & Caragana microphylla & $>40$ \\
\hline F3 & & Semifixed dune & Sand & 198.20 & Salix gordejevii & 20 to 40 \\
\hline B1 & GTS & Fixed dune & Sand & 190.13 & Artimisia halodendron & $>40$ \\
\hline B3 & & Fixed dune & Sand & 191.30 & Artimisia halodendron & $>40$ \\
\hline D2 & & Meadow & Sandy loam & 189.03 & Leymus chinensis & $>50$ \\
\hline $\mathrm{F} 2$ & & Semifixed dune & Sand & 196.62 & Artimisia halodendron & 20 to 40 \\
\hline
\end{tabular}

\section{Water table \\ fluctuation and its effects on vegetation}

L. Duan et al.

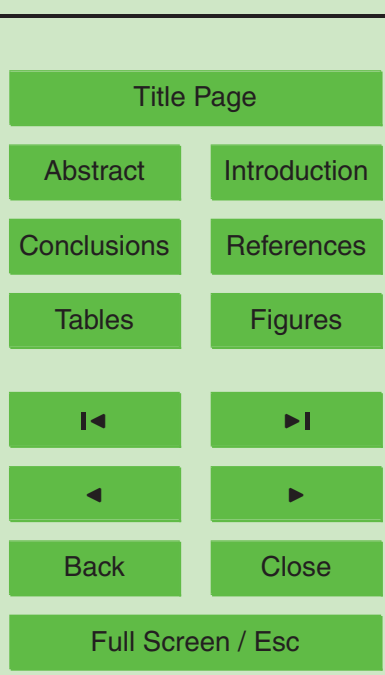

Printer-friendly Version

Interactive Discussion 


\section{HESSD}

8, 3271-3304, 2011

\section{Water table \\ fluctuation and its \\ effects on vegetation}

Table 2. The list of measured parameters ${ }^{1}$.

\begin{tabular}{llll}
\hline Parameter & Definition & Measurement method & Measurement year \\
\hline WT $(\mathrm{m})$ & Water table & Transducer & Apr 2003 to Dec 2009 \\
$R(\mathrm{~mm})$ & Rainfall & Siphon gauge & Jun 2006 to Dec 2009 \\
$\mathrm{SF}(\mathrm{mm})$ & Snowfall & Weighing gauge & Jun 2006 to Dec 2009 \\
$\mathrm{SD}(\mathrm{h})$ & Sunshine duration & Sunshine instrument & Jun 2007 to Dec 2009 \\
$R(\mathrm{~mm})$ & Rainfall & Sensor & Jun 2007 to Dec 2009 \\
$T\left({ }^{\circ} \mathrm{C}\right)$ & Air temperature & Sensor & \\
$\mathrm{RH}(\%)$ & Relative humidity & Sensor & \\
$\mathrm{WS}\left(\mathrm{m} \mathrm{s}^{-1}\right)$ & Wind speed & Sensor & \\
$\mathrm{BP}(\mathrm{hPa})$ & Barometric pressure & Sensor & \\
\hline
\end{tabular}

${ }^{1} R$ (siphon gauge), SF, and SD were measured at $1 \mathrm{~m}$ above the ground surface on a daily basis. $R$ (sensor) was measured at $1 \mathrm{~m}$, and $T, \mathrm{RH}, \mathrm{WS}$, and $\mathrm{BP}$ were measured at $2 \mathrm{~m}$ above the ground surface on acquisition time interval of $30 \mathrm{~min}$.

L. Duan et al.

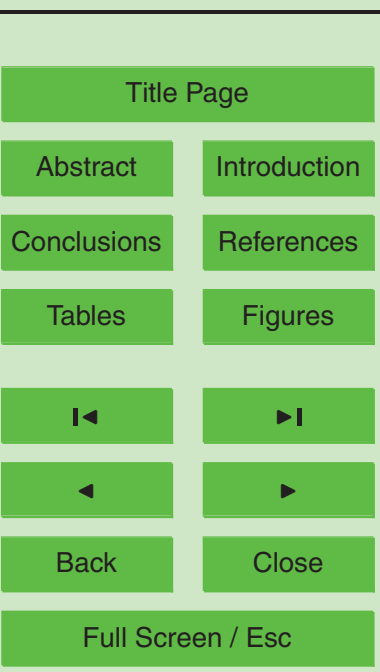

Printer-friendly Version

Interactive Discussion 


\section{HESSD}

8, 3271-3304, 2011

Table 3. Characteristics of the automated sensors.

\begin{tabular}{|c|c|c|c|c|}
\hline Model & Manufacture & Parameter $^{1}$ & Accuracy $^{2}$ & Installation site ${ }^{3}$ \\
\hline PC-2X & $\begin{array}{l}\text { Yangguang Co. Ltd. } \\
\text { (http://jz322.shuoyi.com) }\end{array}$ & WT (m) & $( \pm 0.01)$ & All sites \\
\hline DSJ-2 & $\begin{array}{l}\text { Huayan Co. Ltd. } \\
\text { (http://www.chem17.com) }\end{array}$ & $R(\mathrm{~mm})$ & $( \pm 0.1)$ & KTS \\
\hline TRM-ZF1 & $\begin{array}{l}\text { Yangguang Co. Ltd. } \\
\text { (http://jz322.shuoyi.com) }\end{array}$ & $\mathrm{SF}(\mathrm{mm})$ & $( \pm 0.17)$ & \\
\hline SLR-I & $\begin{array}{l}\text { JWFU Co. Ltd. } \\
\text { (http://www.jwfu.com) }\end{array}$ & SD (h) & $( \pm 0.05)$ & \\
\hline L3 & $\begin{array}{l}\text { Yangguang Co. Ltd. } \\
\text { (http://jz322.shuoyi.com) }\end{array}$ & $R(\mathrm{~mm})$ & $( \pm 0.1)$ & \\
\hline TRM-WD120 & $\begin{array}{l}\text { Yangguang Co. Ltd. } \\
\text { (http://jz322.shuoyi.com) }\end{array}$ & AT $\left({ }^{\circ} \mathrm{C}\right)$ & $( \pm 0.1)$ & \\
\hline PC-2WS4 & $\begin{array}{l}\text { Yangguang Co. Ltd. } \\
\text { (http://jz322.shuoyi.com) }\end{array}$ & $\mathrm{RH}(\%)$ & $( \pm 1.0)$ & \\
\hline PC-2F & $\begin{array}{l}\text { Yangguang Co. Ltd. } \\
\text { (http://jz322.shuoyi.com) }\end{array}$ & WS $\left(\mathrm{m} \mathrm{s}^{-1}\right)$ & $( \pm 0.2)$ & \\
\hline PC-2-T & $\begin{array}{l}\text { Yangguang Co. Ltd. } \\
\text { (http://jz322.shuoyi.com) }\end{array}$ & $\mathrm{BP}(\mathrm{hPa})$ & $( \pm 0.2)$ & \\
\hline MODIS & $\begin{array}{l}\text { National Aeronautics and } \\
\text { Space Adiministration } \\
\text { http://modis.gsfc.nasa.gov/ }\end{array}$ & NDVI & $\begin{array}{c}\text { Resolution } \\
250 \mathrm{~m} \times 250 \mathrm{~m}\end{array}$ & \\
\hline
\end{tabular}

${ }^{1}$ The symbols are defined in Table 2.

2 The accuracy noted in the parenthesis was determined based on the manufacturer's specifications, field calibration, and/or literature values (e.g., Wang, et al., 2007).

${ }^{3}$ See Table 1 and Fig. 1.

\section{Water table \\ fluctuation and its effects on vegetation}

L. Duan et al.

\section{Title Page}

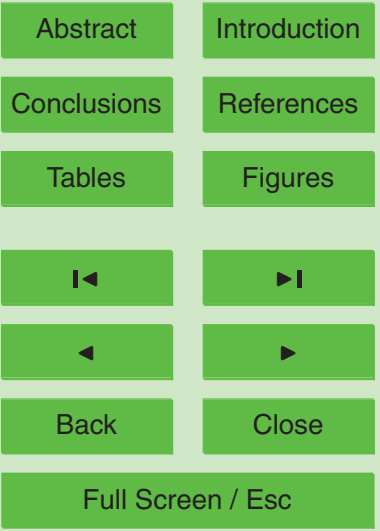

Printer-friendly Version

Interactive Discussion 


\section{HESSD}

8, 3271-3304, 2011

\section{Water table \\ fluctuation and its effects on vegetation}

L. Duan et al.

Table 4. Values for annual mean water table underneath the study area.

\begin{tabular}{lllll}
\hline \multirow{2}{*}{ Temporal scale } & \multicolumn{4}{c}{ Land cover } \\
\cline { 2 - 5 } & $\begin{array}{l}\text { Sandy } \\
\text { dune } \\
(\mathrm{m})\end{array}$ & $\begin{array}{l}\text { Transitional } \\
\text { zone } \\
(\mathrm{m})\end{array}$ & $\begin{array}{l}\text { Meadow } \\
\text { land } \\
(\mathrm{m})\end{array}$ & Lake \\
& 189.11 & 188.31 & 188.20 & 186.60 \\
\hline Spring (Mar to May) & 189.10 & 188.27 & 188.07 & 186.60 \\
Summer (Jun to Aug) & 189.08 & 188.17 & 188.09 & 186.50 \\
Fall (Sep to Nov) & 189.04 & 188.17 & 188.14 & 186.50 \\
Winter (Dec to Feb) & 189.09 & 188.23 & 188.13 & 186.50 \\
Annual & & & &
\end{tabular}

Title Page

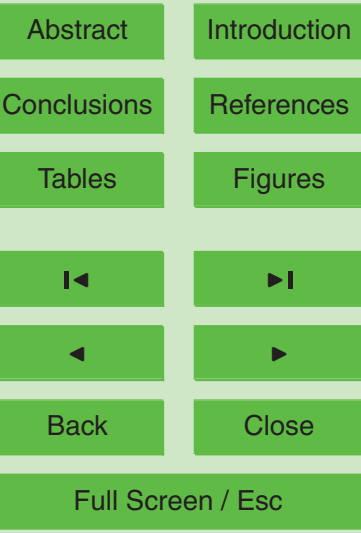

Printer-friendly Version

Interactive Discussion 


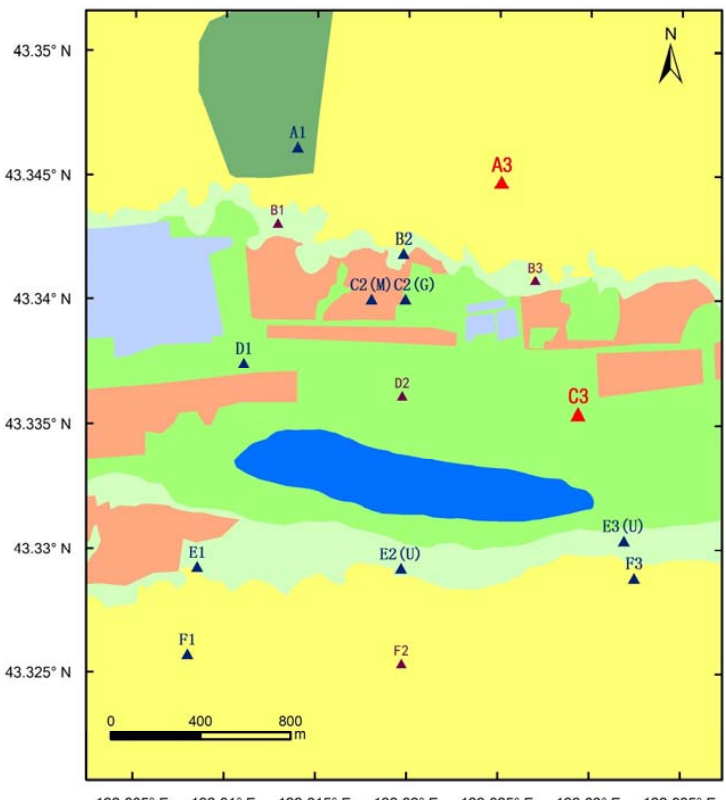

$\begin{array}{ll}\Delta & \text { KTS } \\ \wedge & \text { GKTS }\end{array}$

^ GTS Sandy Land Meadow

Transitional Zone Agricultural Land Lake

Woodland

Residential Area
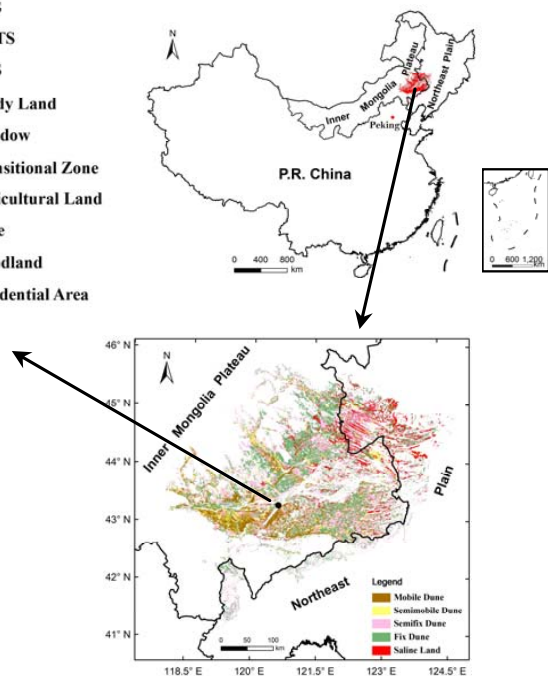

$\begin{array}{lllllll}122.605^{\circ} \mathrm{E} & 122.61^{\circ} \mathrm{E} & 122.615^{\circ} \mathrm{E} & 122.62^{\circ} \mathrm{E} & 122.625^{\circ} \mathrm{E} & 122.63^{\circ} \mathrm{E} & 122.635^{\circ} \mathrm{E}\end{array}$

Fig. 1. The location and landscape features of the study area, and the water table and meteorological stations (KTS, GKTS, and GTS).

\section{HESSD}

8, 3271-3304, 2011

\section{Water table \\ fluctuation and its effects on vegetation}

L. Duan et al.

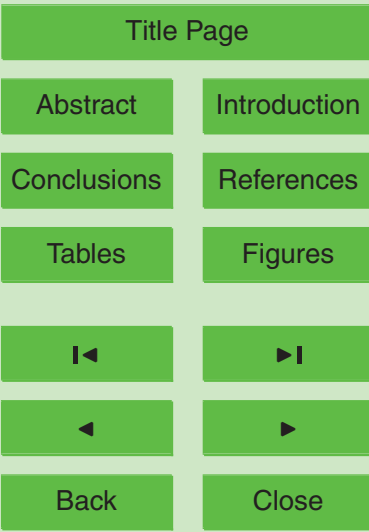

Full Screen / Esc

Printer-friendly Version

Interactive Discussion 

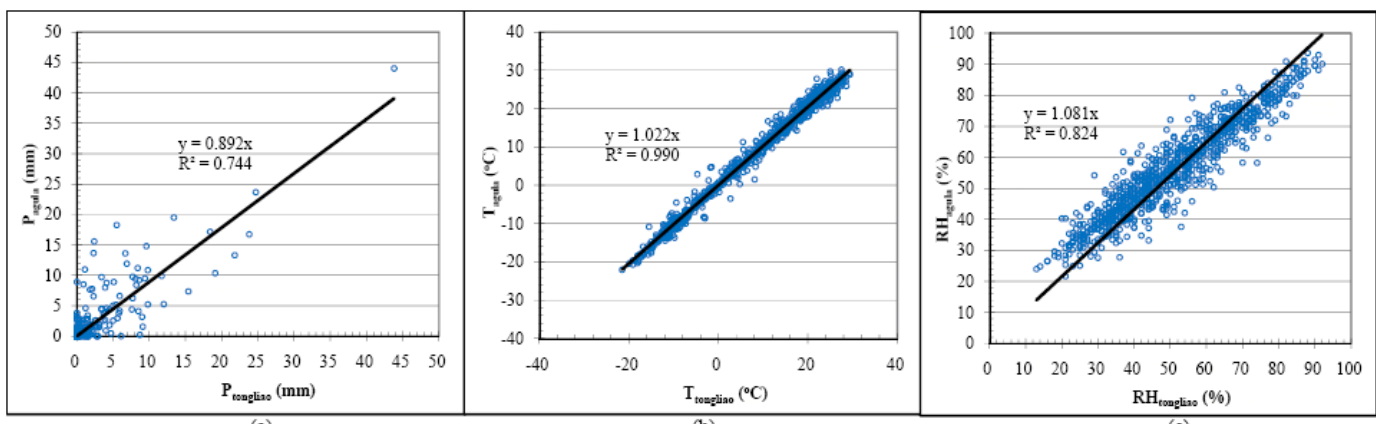

(a)
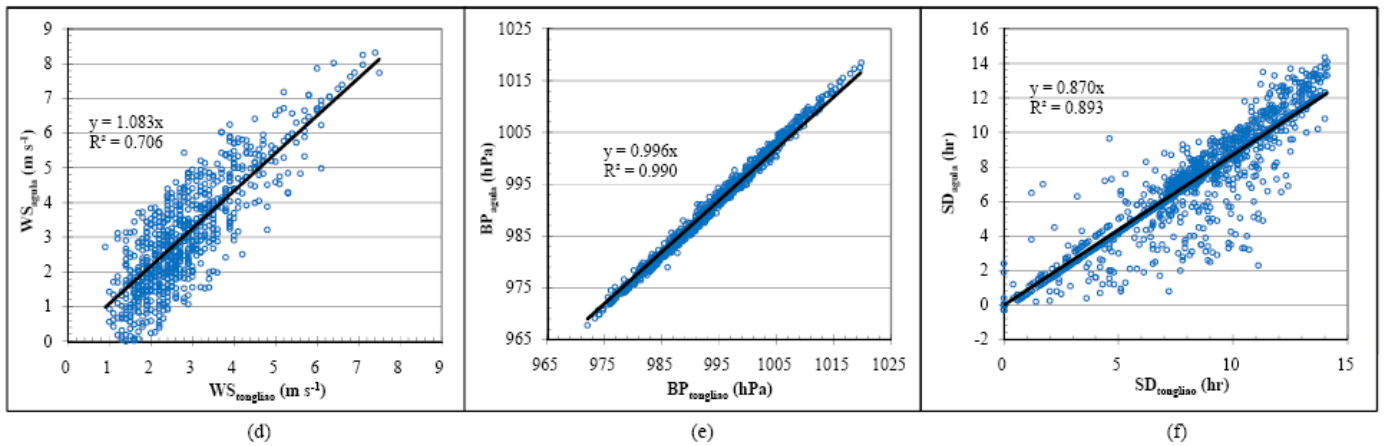

Fig. 2. Regression plots between the study area ("agula") and the Tongliao station ("tongliao") measured daily: (a) precipitation $(P)$; (b) air temperature $(T)$; (c) relative humidity $(\mathrm{RH})$; (d) wind speed (WS); (e) barometric pressure (BP); and (f) sunshine duration (SD).

\section{HESSD}

8, 3271-3304, 2011

\section{Water table \\ fluctuation and its effects on vegetation}

L. Duan et al.

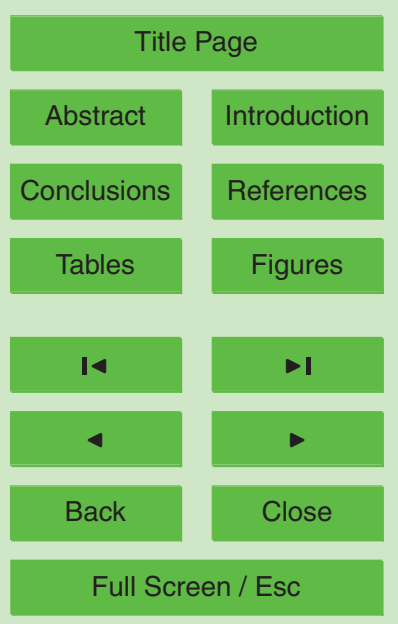

Printer-friendly Version

Interactive Discussion 


\section{HESSD}

8, 3271-3304, 2011

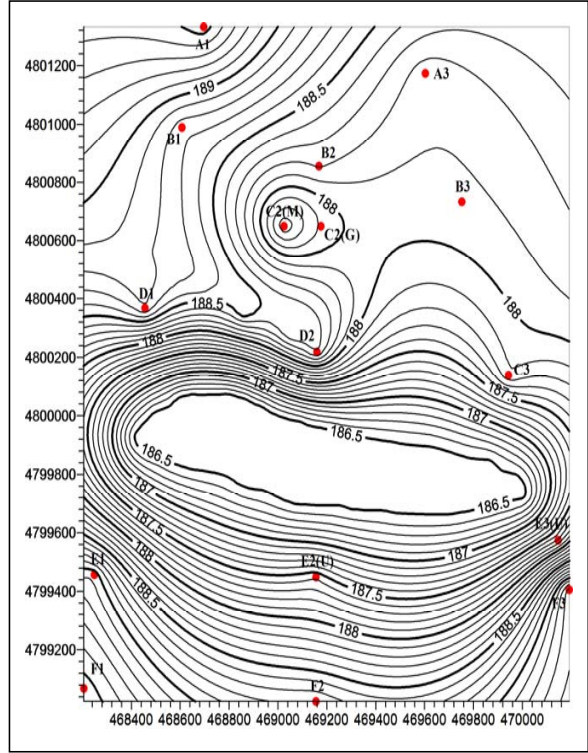

(a)

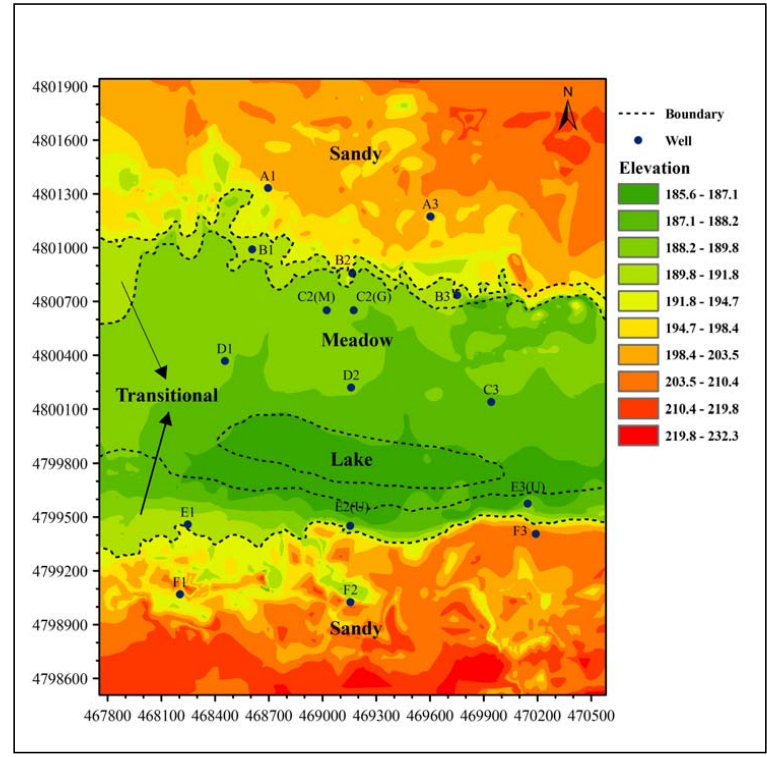

(b)

Fig. 3. a, b The contour of: (a) annual mean annual water table, (b) topography, (c) annual mean spring water table, (d) annual mean summer water table, (e) annual mean fall water table, and (f) annual mean winter water table. The units are in $\mathrm{m}$ and dots signify the sampling wells.

Water table

fluctuation and its effects on vegetation

L. Duan et al.

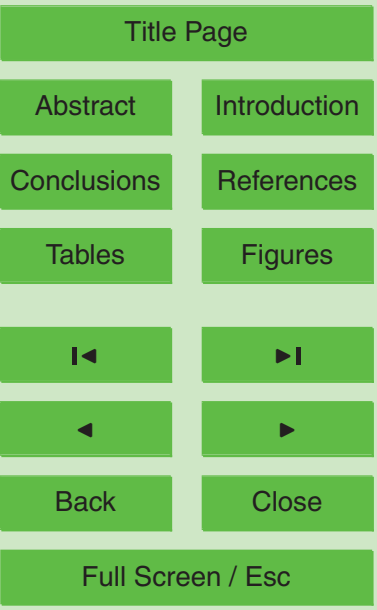

Printer-friendly Version

Interactive Discussion 


\section{HESSD}

8, 3271-3304, 2011

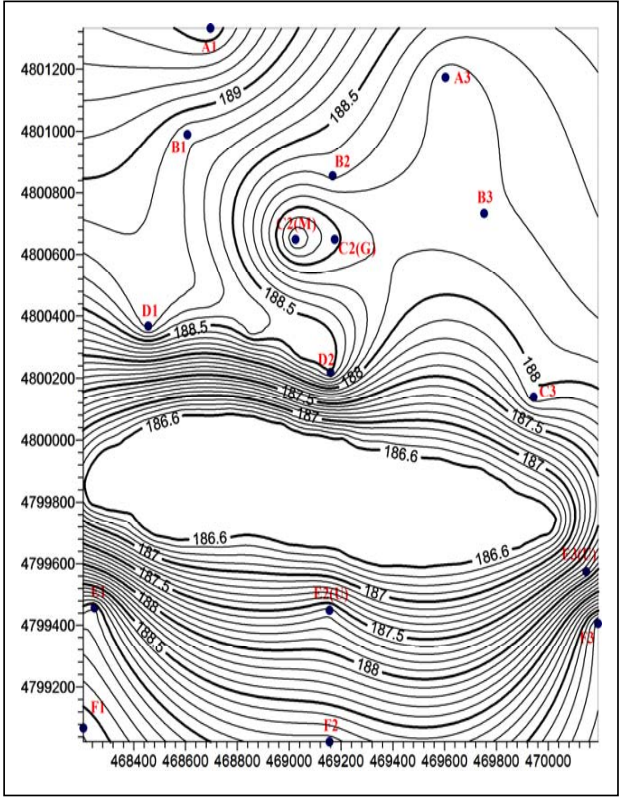

(c)

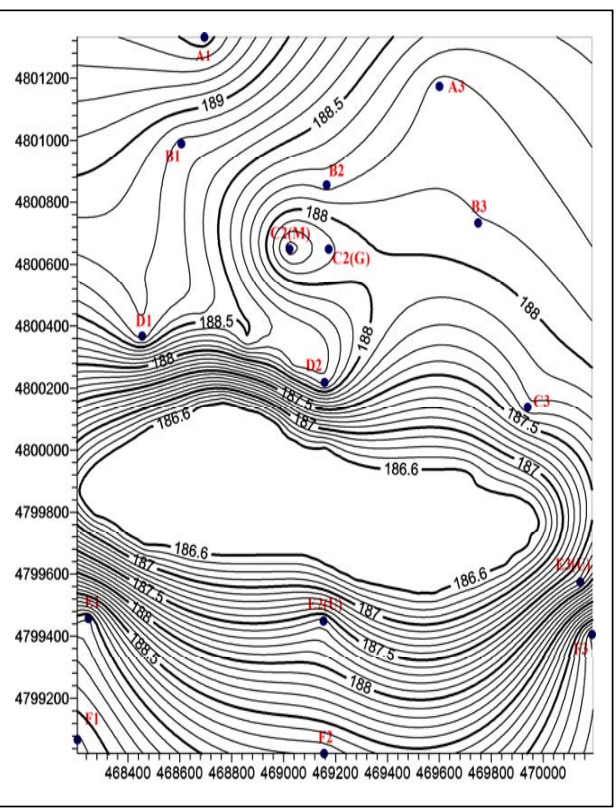

(d)

Fig. 3. c, d Continued.

Water table

fluctuation and its effects on vegetation

L. Duan et al.

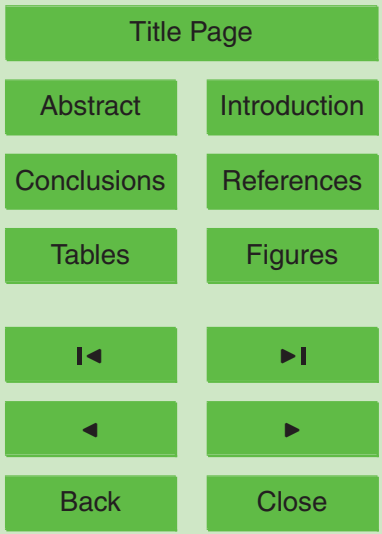

Full Screen / Esc

Printer-friendly Version

Interactive Discussion 


\section{HESSD}

8, 3271-3304, 2011

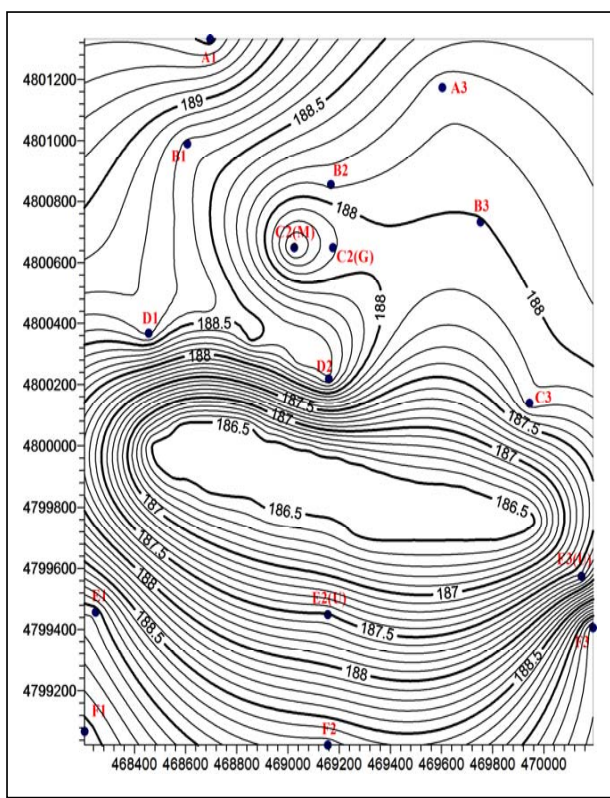

(e)

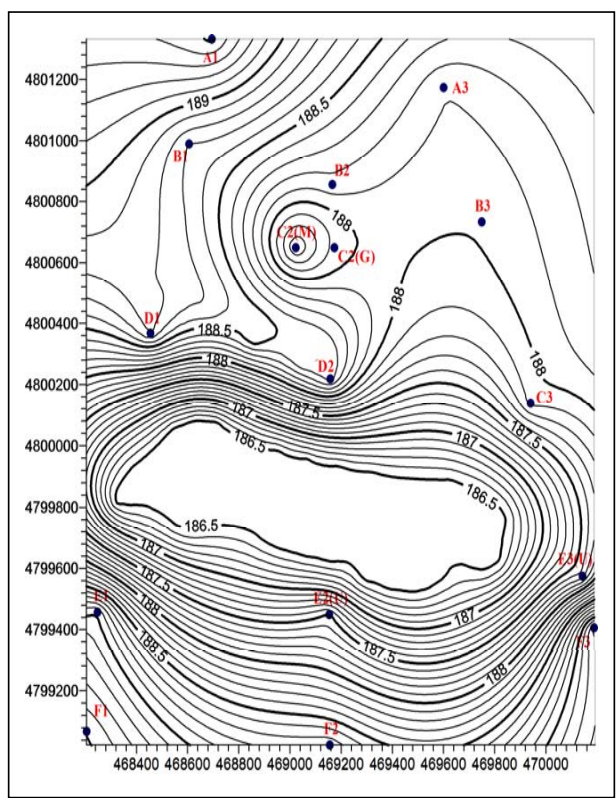

(f)

Fig. 3. e, f Continued. 


\section{HESSD}

8, 3271-3304, 2011

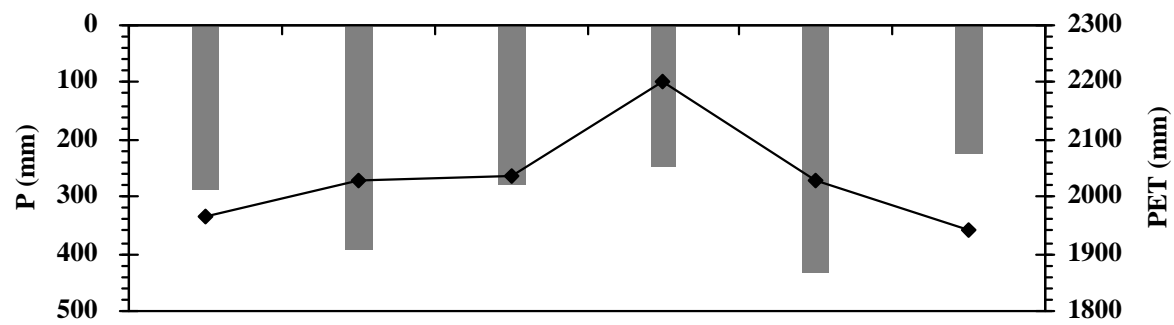

\section{Water table \\ fluctuation and its effects on vegetation}

L. Duan et al.

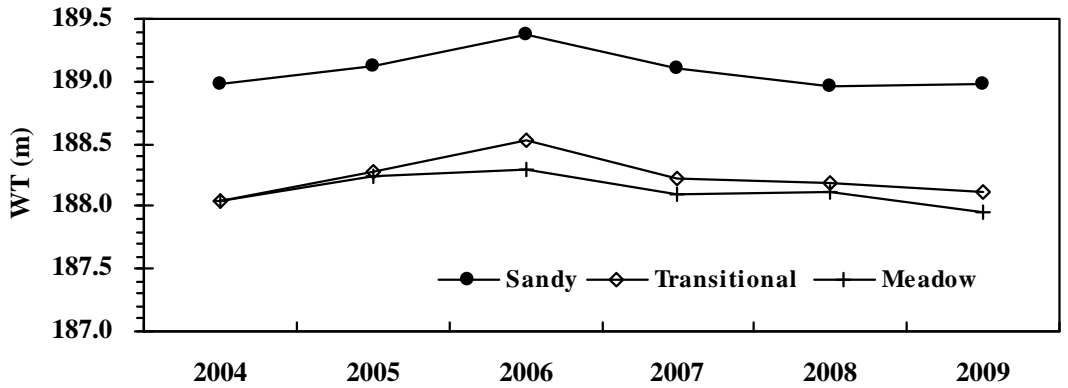

Title Page

Abstract Introduction

Conclusions

References

Tables

Figures

14

4

Back

Close

\section{Full Screen / Esc}

Printer-friendly Version

Interactive Discussion 


\section{HESSD}

8, 3271-3304, 2011

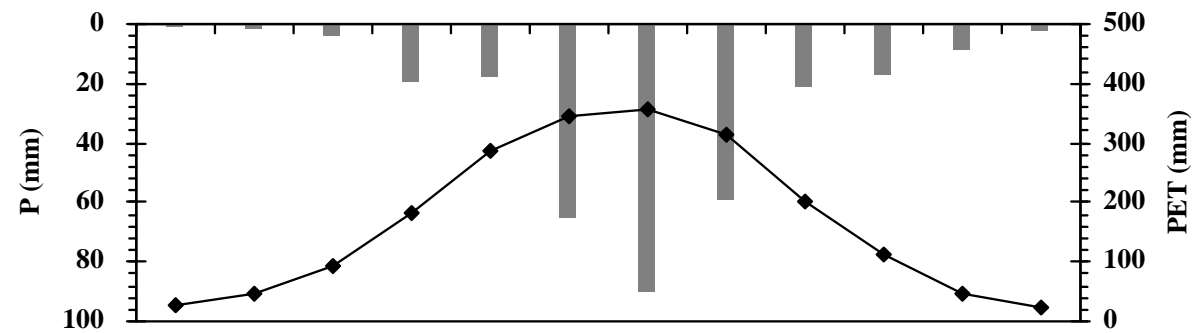

\section{Water table \\ fluctuation and its effects on vegetation}

L. Duan et al.

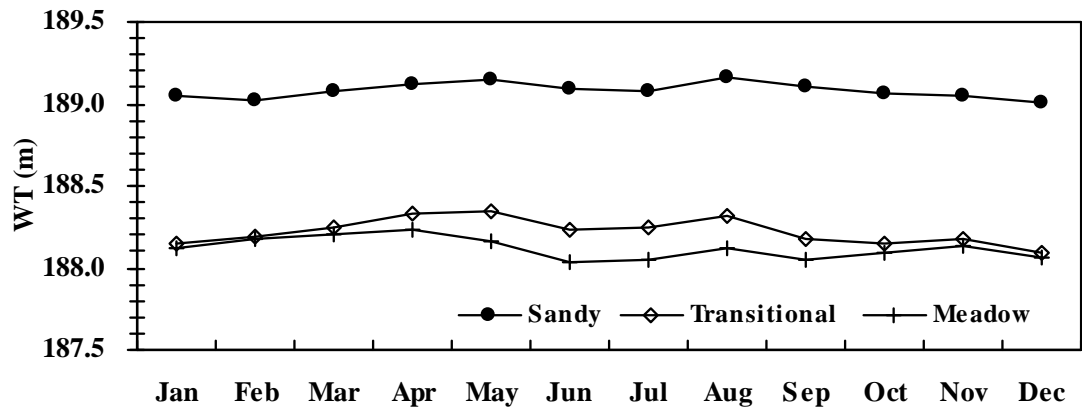

Fig. 5. Responses of annual mean monthly water table (WT) to annual mean monthly precipitation $(P)$ and potential evapotranspiration (PET) for the three land covers of the study area. The average ground elevation is $212.0 \mathrm{~m}$ for the sandy areas (Sandy), $190.0 \mathrm{~m}$ for the transitional zones (Transitional), and $188.5 \mathrm{~m}$ for the meadow lands (Meadow).

\section{Full Screen / Esc}

Printer-friendly Version

Discussion 

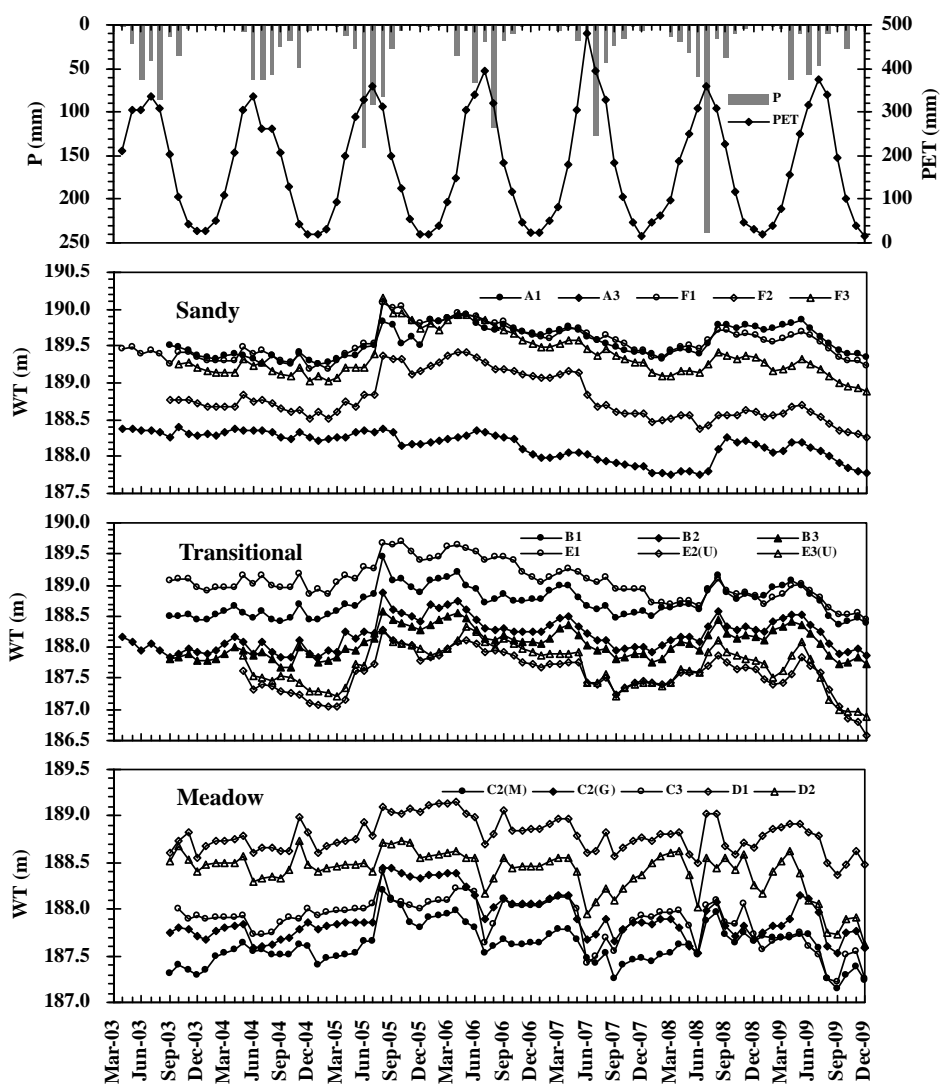

Fig. 6. Responses of mean monthly water table (WT) to cumulative monthly precipitation $(P)$ and potential evapotranspiration (PET) for the three land covers of the study area. The average ground elevation is $212.0 \mathrm{~m}$ for the sandy areas (Sandy), $190.0 \mathrm{~m}$ for the transitional zones (Transitional), and $188.5 \mathrm{~m}$ for the meadow lands (Meadow).

\section{HESSD}

$8,3271-3304,2011$

\section{Water table \\ fluctuation and its effects on vegetation}

L. Duan et al.

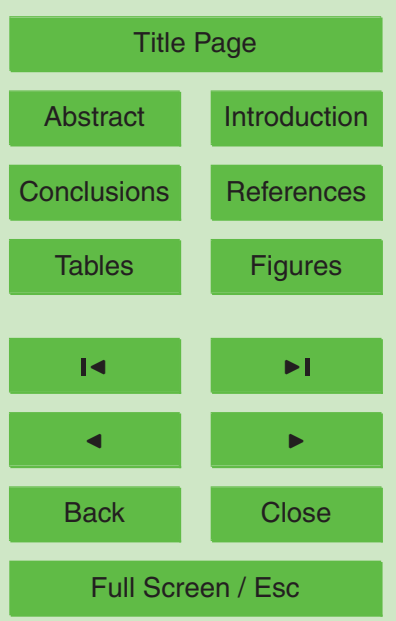

Printer-friendly Version

Interactive Discussion 


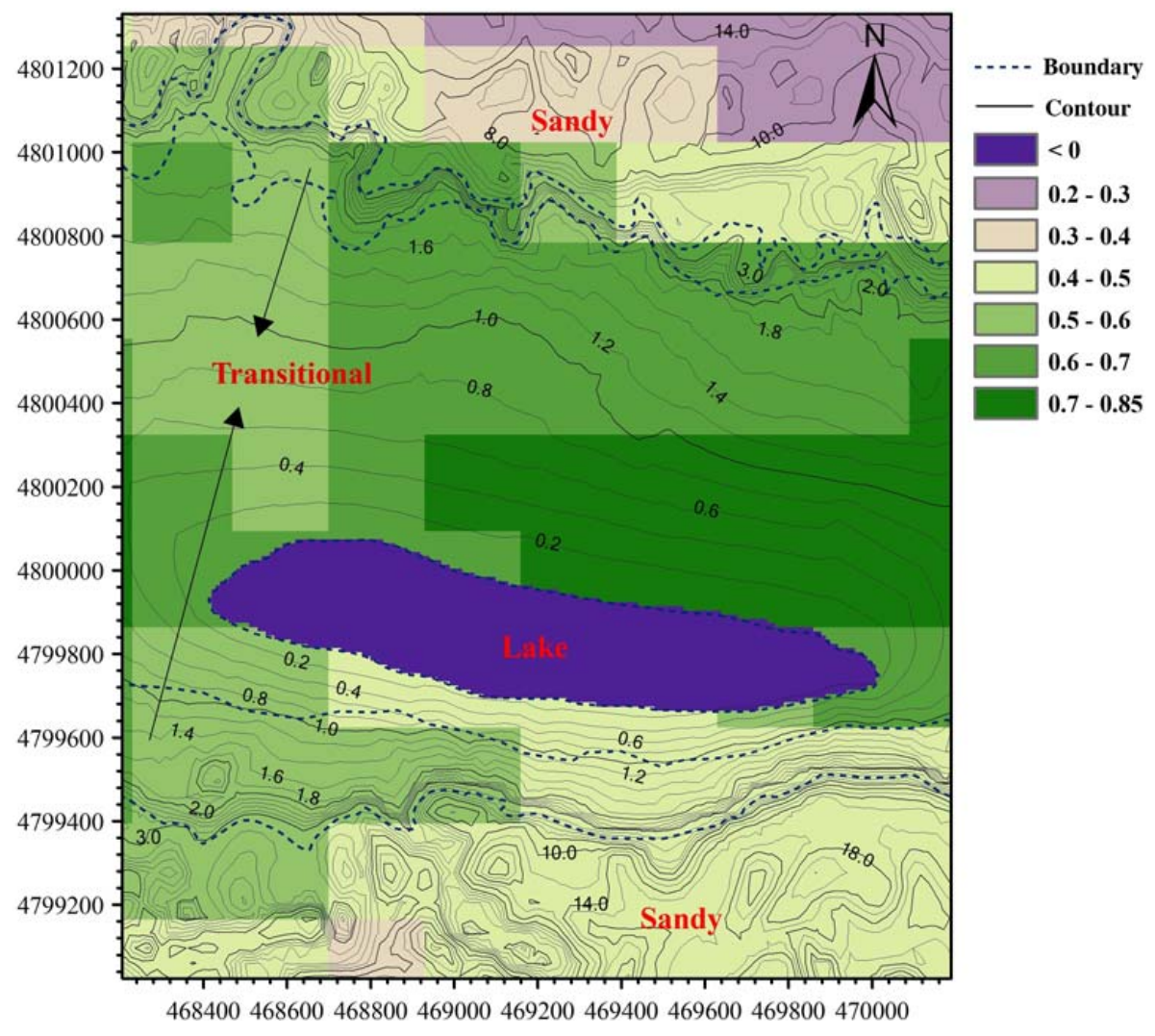

Fig. 7. Map showing the contours of annual mean annual depth to water table and the annual mean maximum Normalized Difference Vegetation Index (NDVI) grids. A contour interval of $0.2 \mathrm{~m}$ was used for depths of less than $2 \mathrm{~m}$, an interval of $1 \mathrm{~m}$ used for depths between 3 and $8 \mathrm{~m}$, and an interval of $2 \mathrm{~m}$ used for depths of greater than $8 \mathrm{~m}$.

\section{HESSD}

8, 3271-3304, 2011

\section{Water table \\ fluctuation and its effects on vegetation}

L. Duan et al.

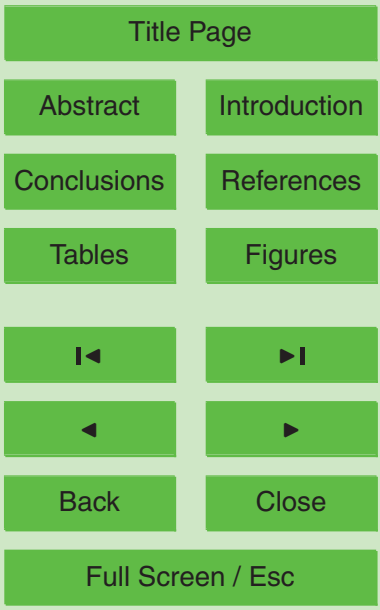

Printer-friendly Version

Interactive Discussion 


\section{HESSD}

8, 3271-3304, 2011

\section{Water table \\ fluctuation and its effects on vegetation}

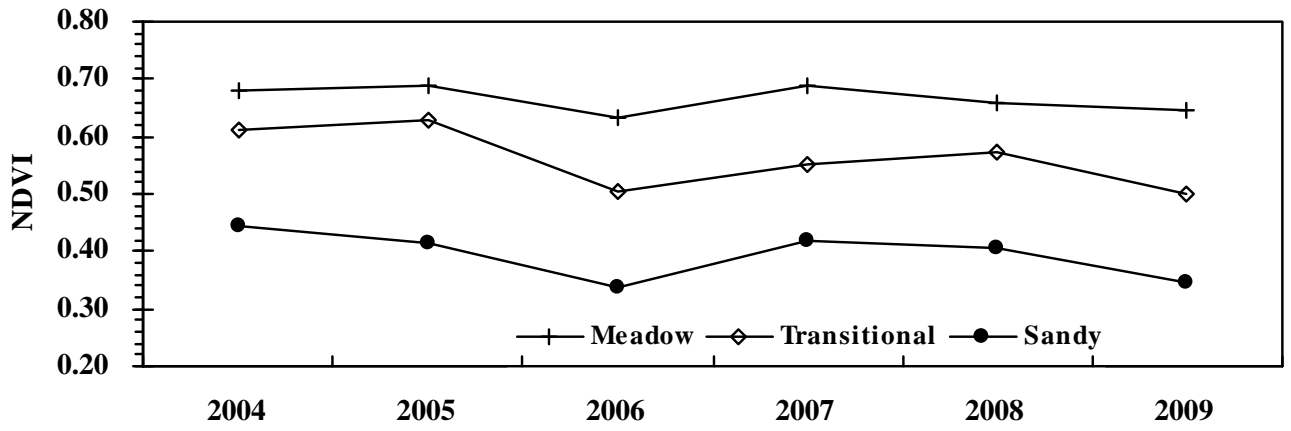

L. Duan et al.

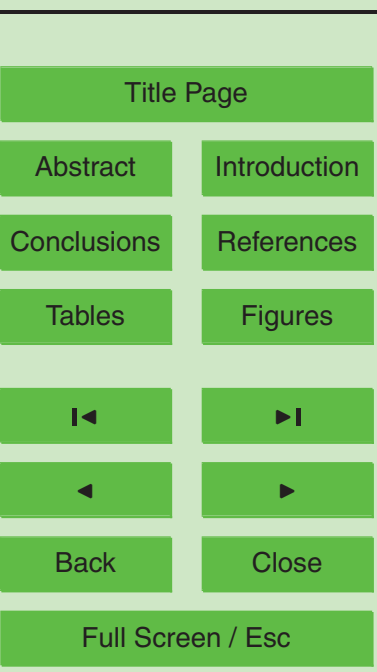

Printer-friendly Version

Fig. 8. Plot showing mean annual values for maximum Normalized Difference Vegetation Index (NDVI) averaged across the meadow lands (Meadow), the transitional zones (Transitional), or the sandy dunes (Sandy), of the study area. 